\title{
Concentration of $\mathrm{I}_{2}, \mathrm{Na}, \mathrm{K}, \mathrm{Mg}$ and $\mathrm{Fe}^{2+}$ in Soils, Plants, Ash and Salt Samples of Selected Areas of Western Kenya
}

\author{
Wangila Tsikhungu Phanice ${ }^{1}$, Kinyanjui Thomas ${ }^{2}$, Nakhone Lenah N. ${ }^{3}$ \\ ${ }^{1}$ University of Kabianga, School of Science and Technology, P.O box 2030, Kericho, Kenya \\ ${ }^{2}$ Kinyanjui Thomas, Egerton University, Chemistry Department, P.O box 536, Njoro, Kenya \\ ${ }^{3}$ Nakhone Lenah N., Egerton University, Department of Soil Science, P.O box 536, Njoro, Kenya
}

\begin{abstract}
Table salt is one of the most used food additives with a unique place in food consumption. The chemical and physical composition of traditional salts is not well understood. Two types of reeds from Lugari and Busia regions of western Kenya were studied to establish the concentration of selected nutrients and determine some of the factors affecting the micronutrient content. Cyperus papyrus and Typha latifolia reeds of Lugari and Busia regions respectively, grow in weak acidic soils of pH range from 4.9-6.5. It was observed that an increase in the soil's percentage clay content increases CEC while an increase in soil bulk density decreases the soil's $C E C$. Soil iodine was found to depend largely on depth, SBD, percentage clay clay and moisture. An increase in depth led to a decrease in iodine level in soil with the top soils $(0-15 \mathrm{~cm}$ ) recording higher iodine content than sub-soils (15-30 cm deep). As iodine increased with increase in SBD and \% clay, $\mathrm{Fe}^{2+}$ concentration increased with increase in depth in the dry season. There was higher concentration of iodine in Cyperus papyrus reeds from Bidimbidi than in Ululo during both the wet and dry seasons. The K content of T. latifolia was higher than that of $C$. papyrus with $K$ levels increasing with increase in iodine concentration in both plants. Busia reeds had more Na and $\mathrm{K}$ than Lugari reeds for both the wet $(2871.8 \mathrm{mg} / \mathrm{kg}>2519 \mathrm{mg} / \mathrm{kg})$ and the dry $(367 \mathrm{mg} / \mathrm{kg}>223 \mathrm{mg} / \mathrm{kg})$ seasons. In the present study, Iodine, $\mathrm{K}, \mathrm{Na}$, concentrations increased with ashing process while a decrease in $\mathrm{Mg}$ was noted. The concentrations of $\mathrm{K}$ and $\mathrm{Na}$ were higher in soils than in plants with a Tf ranking order of $\mathrm{Na}>\mathrm{K}>\mathrm{Mg}>\mathrm{I}$ for both Busia and Lugari regions. The order of decreasing concentration of the micronutrients in the salt was of the form $\mathrm{Na}>\mathrm{K}>\mathrm{Mg}$ for Busia while for Lugari it was $\mathrm{K}>\mathrm{Na}>\mathrm{Mg}$. On average, Busia Cyperus papyrus salt had higher $\mathrm{Na}$, $\mathrm{pH}$ and moisture content but lower K, 11,930 mg/kg, 10.3, $10.1 \%$ and 3,736.2 $\mathrm{mg} / \mathrm{kg}$ compared to Lugari Typha latifolia salt whose $\mathrm{Na}, \mathrm{K}, \mathrm{pH}$ and moisture are $3,943.8 \mathrm{mg} / \mathrm{kg}, 4,635.8 \mathrm{mg} / \mathrm{kg}, 9.7 \mathrm{and} 0.8 \%$ respectively. . Lugari salt samples had a Na:K ratio of 0.9 while Busia's C. papyrus salt had a Na:K ratio of 3.2. Comparing the Na: K ratio of the types of reed salts, T. latifolia has 0.85:1 while C. papyrus has 3.2:1 compared to 4:1 recommended by WHO 2006. From the results, Cyperus papyrus salt may be a better and ideal food salt than Typha latifolia.
\end{abstract}

Keywords: Typha latifolia, Cyperus papyrus, Micronutrients

\section{Introduction}

Table salt is one of the mostly used food additive with unique place in food consumption (Soylak et al., 2008). Its production is one of the most ancient and widely distributed industries in the world. The physical and chemical composition of salt produced from the various sources varies widely depending upon the climatic conditions, source, techniques, and processes adopted. Edible salt is biologically necessary because it provides two important macro elements of sodium and chlorine for human body. Furthermore, it improves food taste, could serve as a preservative, and elongates shelf life. Today most people have become accustomed to the taste of salt such that its consumption has increased despite the numerous diseases it is associated with like hypertension, cardiovascular and kidney diseases (Jean et al., 2015). Because of the damage salt does on the human health, many consumers and especially in Africa prefer vegetable salt from ash obtained by burning plant parts which are expected to be potassium rich.

In East Africa, indigenous plant salt is still traditionally produced and consumed either by alimentary habit or for therapeutic reasons. It is used as a substitute of modern salt for atrophic gastritis, for icterus, to lower the blood pressure and as sedative against cough (Allaramadji, 2011).
Communities around the Lake Victoria such as the Samia/Luhya communities in Western province of Kenya, the Kwaya/Kurya communities of Mara region, Tanzania and the Basoga communities in Uganda are known to harvest and use traditional salts from different plants (Kabaija, 1989; King'ang'a, 2005). The main plant materials come from beans, (Fassiola vulgaris), maize, (Zea mays) and papyrus reeds (Cyperus papyrus and Typha latifolia species) among others. Western Kenya is one of the regions where plant derived salts arelargely used with its salt being processed as ashes upon burning some plant materials (King'ang'a, 2005). In Lugari and Busia regions of Western Kenya, unrefined indigenous salts are obtained from papyrus reed plants (Keter et al., 2011). This salt is especially used in foodstuffs like indigenous vegetables, meat, and other meals by the local people and constitutes one of the major ingredients in the local staple.The consumption of unrefined salts with unspecified elemental concentrations can have far reaching health consequences if such salts contain hazardous contaminants.

Several physical and chemical factors affect the micronutrients availability and uptake by plants from the soil. This includes: Soil organic matter, soil clay content, soil, temperature and moisture and soil $\mathrm{pH}$. As soil $\mathrm{pH}$ increases, the availability of the micronutrients decreases 


\section{International Journal of Science and Research (IJSR) \\ ISSN (Online): 2319-7064 \\ Index Copernicus Value (2013): 6.14 | Impact Factor (2015): 6.391}

due to the chemical reactions where the micronutrients are complexed. Apart from the total amount of micronutrient in the soil and the soil properties, the plant species and variety can also influence the availability of the nutrients in the growing plant and eventually in the food chain. For instance the availability of iodine as one of the micronutrients, in the absence of dietary seafood sources depends largely on its transfer from soil to food and fodder crops (Johnson et al., 2002; Johnson, 2003). There is therefore a need to increase understanding of iodine behaviour in soils if the resulting implications for transfer to crops, human and livestock are to be understood. The lack of iodine in the soil and water and thus in food, leads to iodine-deficiency disorders, which include goiter and a wide spectrum of mental and intellectual defects with varying degrees of severity. This includes cretinism, paralysis, and deaf-mutism (Fuge, 2007). Iodine Deficiency disorders (IDD) can also lead to stunted growth and development, miscarriages, stillbirths, and infant deaths (Johnson, 2003).

This section of the study was aimed at assessing the level of some essential elements ( $\mathrm{Na}, \mathrm{K}, \mathrm{Mg}$, I and $\mathrm{Fe}^{2+}$ ) in Cyperus papyrus and Typha latifolia reed salts. From the findings, values of estimate daily intake of the heavy metals in the salt samples were calculated to estimate the risk to human health. However, lack of knowledge of the elemental constituents of these reed salts often poses danger to consumers as some may contain toxic elements. Also, the dose rate of many of these reed plants is not well defined and left to the judgment of the users. Thus, screening of the elemental composition of these medicinal plants is highly essential. There are limited studies on the micronutrients content of reed salts from Western Kenya. Much focus has been on the status of metal content in edible vegetables, without considering the salt used in these vegetables.

\subsection{Purpose of the study}

The purpose of this study is to assess the concentration of selected micronutrients $\left(\mathrm{I}_{2}, \mathrm{Na}, \mathrm{K}, \mathrm{Mg}\right.$ and $\left.\mathrm{Fe}^{2+}\right)$ in soils, plants, Ash and Salt Samples in soil habitats of reed plant species of the indigenous salts used in Lugari and Busia regions of Western Kenya. This is an attempt to fill in the knowledge gap regarding the availability of the micronutrients from the soil to the reed plant and consequently to the salt.

\subsection{Materials and Methods}

\subsubsection{Study Area}

The study area comprised of two sites: Lugari and Busia regions of Western Kenya. Two sites were selected from each region, Matete and Lugari villages of Lugari division, in Kakamega region and Ululo and Bidimbidi villages in Matayos division of Busia region of Western Kenya (Figure 1). These regions were chosen based on the common method of processing of unrefined indigenous crystalline salts and the different reed species used in processing of the indigenous salts. Two types of papyrus reeds were used in this study; Cyperus papyrus reeds (Matayos) and Typha latifolia reeds (Lugari). Lugari district comprises of three administrative divisions Likuyani, Matete and Lugari, with a total area of $670.2 \mathrm{~km}^{2}$ where Lugari and Matete divisions are selected in Lugari district for study. Lugari lies at an altitude of $1840 \mathrm{~m}$ above sea level records a mean annual rainfall range of $900-2200 \mathrm{~mm}$ falling within the upper midland (UM) and lower midland (LM) agro-ecological zone. Busia district in Western region covers an area of $1,261.3 \mathrm{~km}^{2}, 137 \mathrm{~km}^{2}$ of which is part of Lake Victoria basin. Busia lies at $1220 \mathrm{~m}$ above sea level, has a rainfall range of 1300-1800 mm falling under lower midland agroecological zone (AEZ).The district is divided into six administrative divisions, namely Nambale, Butula, Funyula, Budalangi, Township and Matayos. Matayos division was randomly selected for this study in Busia district (Republic of Kenya, 2002-2008a). A Global Positioning System (GPS) was used to obtain the grid references of the location of the study sites. 


\section{International Journal of Science and Research (IJSR) \\ ISSN (Online): 2319-7064}

Index Copernicus Value (2013): 6.14 | Impact Factor (2015): 6.391

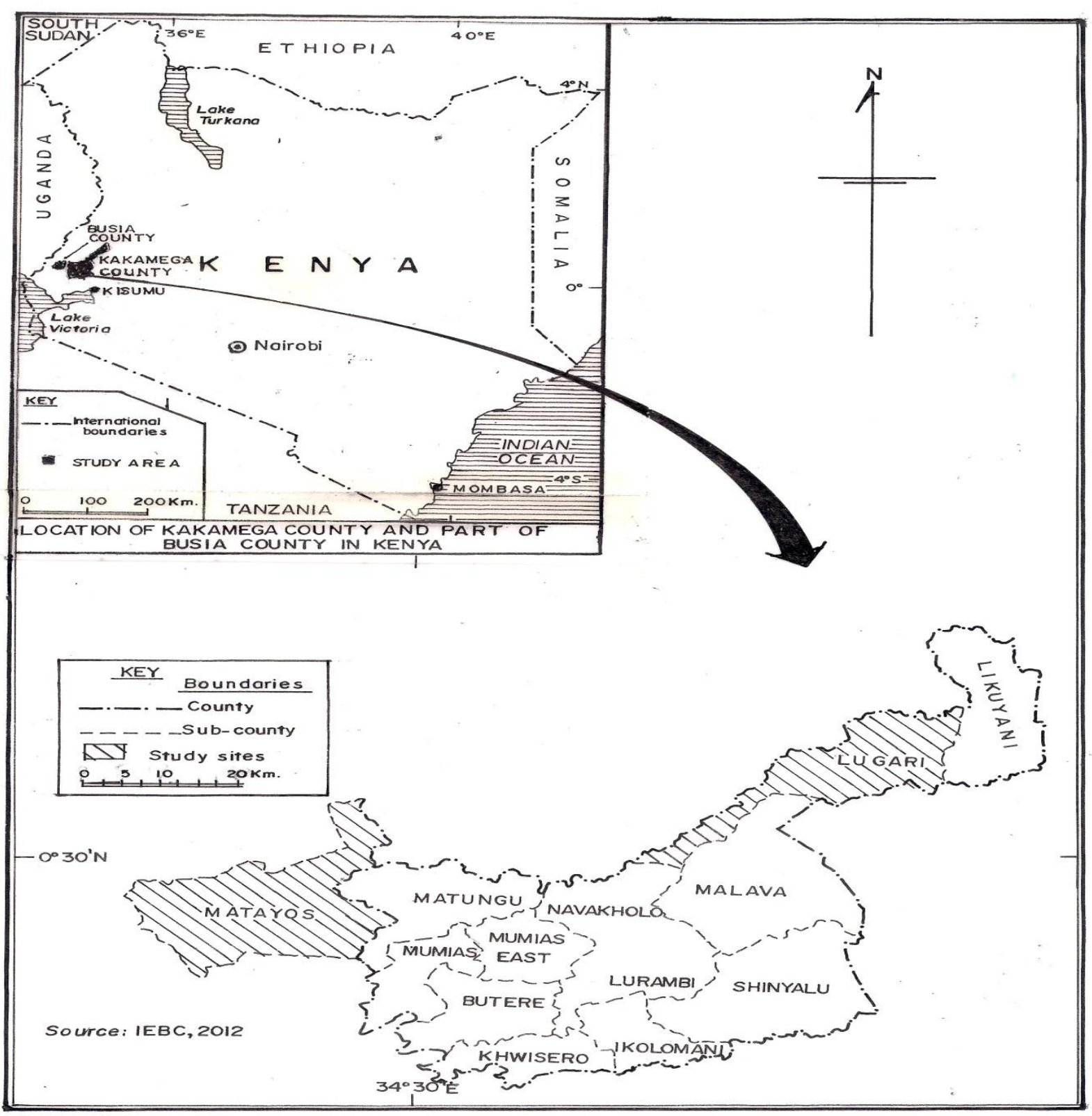

Figure 1: Map of Kenya Showing the sampling areas in Western Province

\subsubsection{Sample Collection}

Samples were collected from the selected sites in Lugari and Busia regions of Western Kenya, (Figure 1) using randomized method. The samples were collected during both the wet (March-Aug) and dry (Jan-March) periods between January 2012 and December 2013. Soil and plant samples were obtained from randomly selected sites in each region. Top-soil $(0-15 \mathrm{~cm} \mathrm{depth})$ and sub-soil $(15-30 \mathrm{~cm} \mathrm{depth})$ samples were collected into separate polyethylene plastic bags from randomly selected sampling points within a $10 \mathrm{~m}$ square plot of landby the 5 points mixture method from a 10 $\mathrm{m}$ square plot of land (Provisional manual for soil survey related to dioxins, 1998). Approximately $0.5 \mathrm{~kg}$ (wet weight) of soil samples was scooped using a clean stainless steel auger and a corer for bulk density determination, while a mud (Dutch) auger was used to obtain the wet clay boggy soil for Busia soil samples since the place is swampy. One was taken from the center of the plot, and the others from points between 5 to $10 \mathrm{~m}$ in each of four directions, from the same sampling area. They were mixed to form one pooled soil for top-soil $(0-15 \mathrm{~cm}$ depth) and sub-soil $(15-30 \mathrm{~cm})$ samples respectively. From each of the above sampling sites used for soils, about $200 \mathrm{~kg}$ full growth stage ( 8 months) fresh reed samples were collected using a stainless steel knife and mixed as well to obtain a $1 \mathrm{~kg}$ pooled sample per site. The plants were thoroughly washed with tap water to remove surface sand. From the same sampling areas, ash from reeds was collected from randomly selected homes, burnt from the reeds plants obtained from similar sampling sites as mentioned above. The salts were collected together with ash samples from respective study sites with the consent of local people. A total of 18 salt samples were collected from Busia sites and 15 samples from Lugari making a total of thirty three salt samples. The salt samples were collected using standard sampling methods (Gupta and Sinha, 2007) from randomly selected homesteads on burning of the above collected and well prepared reeds. Prepared salt samples were thoroughly mixed to ensure a uniform mixture. These were mixed to form a $500 \mathrm{~g}$ composite sample for each respective homestead. The samples were 


\section{International Journal of Science and Research (IJSR) \\ ISSN (Online): 2319-7064 \\ Index Copernicus Value (2013): 6.14 | Impact Factor (2015): 6.391}

packed in polythene bags for transportation. The packed soil, plant, ash and salt samples were stored in cool boxes (at 4 ${ }^{\circ} \mathrm{C}$ ) and transported to the laboratory at Egerton University where they were preserved for further analysis.

\subsubsection{Preparation and preservation}

In the laboratory, portions of the cored soil samples were used for moisture determination. The rest of the soil samples were dried in the open in aluminium trays at ambient temperature for 6 days and gently disaggregated using a pestle and mortar where necessary. Samples were homogenized using the 'cone method'. Sieved soil was poured into a cone-shaped pile and strips from the cone base to the top used to build a new cone and the entire process repeated four times (Schumacher et al., 2010). The homogenised soil samples were crushed and finely ground using a Moulinex coffee and spice mill, model 980. Solid ingredients were mixed using a $5 \mathrm{~L}$ ribbon blender from the Department of Soil Science, Egerton University. Finely ground soil samples were sieved through a $2 \mathrm{~mm}$ mesh, and then sealed in Kraft paper envelopes prior to analysis.

Plant samples were prepared according to the procedure described by Khan et al., (2006). The plant parts were washed in fresh running water to eliminate dust, dirt, possible parasites or their eggs followed with deionized water. The plants were cut into pieces of about $10 \mathrm{~cm}^{3}$, air dried in the open for 6 days. The dried plant samples were homogenized by grinding using a Retsch, Model PM400 agate ball miller. Finely ground samples were sieved with 2 $\mathrm{mm}$ mesh before being stored in labeled polythene bags at ambient temperature prior to analysis.

Ash samples were prepared by picking the unburned plant material, and packing the rest in polythene backs for further analysis.

\subsection{Sample Analysis}

The chemicals used during the entire study were of analytical grade. A series of standard metal solutions were prepared, as per the standard methods (AOAC, 1996) by appropriate dilution of the respective stock metal solutions. In general, reagents of the highest purity were used whereas for hydrates, fresh reagents were used.

\subsubsection{Determination of $\mathbf{p H}$ in Soil and Salt samples}

The $\mathrm{pH}$ of the soil suspension was measured using a JENWAY pH meter model 3505, at a temperature of $20.8{ }^{\circ} \mathrm{C}$ in triplicate. The $\mathrm{pH}$ meter which consisted of a combined glass electrode (Ag/AgCl; PHE 1004), had earlier been calibrated with $\mathrm{pH} 7$ and $\mathrm{pH} 4$ buffers beforethe analysis of the samples was carried out.

\subsubsection{Determination of Soil Bulk Density}

Using a steel core, an undisturbed flat horizontal surface in the soil was prepared with a spade at the depth of $15 \mathrm{~cm}$ and $30 \mathrm{~cm}$. The steel ring was gently hammered into the soil. Excavation was done around the ring without disturbing or loosening the soil it contained and carefully removed with the soil intact. The soil core was weighed as it was found in the field and air dried. This weight was recorded and the core was placed into an oven at $105^{\circ} \mathrm{C}$ to obtain oven dry
(OD) soil. The OD soil was weighed and the water content calculated by the volume of water $\left(\mathrm{cm}^{3}\right)$ divided by the total volume of soil $\left(\mathrm{cm}^{3}\right)$. Bulk density was calculated by the mass of OD soil (g) divided by the total volume of soil $\left(\mathrm{cm}^{3}\right)$. The volume of the ring was determined by measuring the height of the ring with the ruler in $\mathrm{cm}$ to the nearest $\mathrm{mm}$, and the diameter of the ring to get the radius. Ring volume $\left(\mathrm{cm}^{3}\right)=3.14 x \mathrm{r}^{2} x$ ring height; (Soil volume $=$ ring volume). To calculate the dry weight of the soil, the ovenproof container was weighed in grams $\left(\mathrm{W}_{1}\right)$. The soil was dried for 2 hours in a conventional oven at $105{ }^{\circ} \mathrm{C}$. The dry soil sample was weighed to give $\left(\mathrm{W}_{2}\right)$; (Dry soil weight $(\mathrm{g})=$ $\left(\mathrm{W}_{2}-\mathrm{W}_{1}\right)$ and $\mathrm{p}$ is the $\mathrm{BD}$, equation 1 ;

For,

$$
\text { Bulk Density }=\frac{\left(W_{2}-W_{1}\right)_{(g)}}{\left(3.14 \times \mathbf{r}^{2} \times \mathbf{h}\right)_{\left(\mathrm{cm}^{3}\right)}} 1
$$

Where $(\boldsymbol{W} 2-\boldsymbol{W} 1)(g)=$ soil OD $(g)$

\subsubsection{Determination of Soil Moisture content}

The moisture content of the soil as a percentage of the dry soil weight was calculated using equation 2 below: $M C \%=$ $\left(W_{2}-W_{1}\right)-\left(W_{3}-W_{1}\right) /\left(W_{2}-W_{1}\right) X 1002$

Where:

$\mathrm{W}_{1}=$ Weight of tin $(\mathrm{g})$

$\mathrm{W}_{2}=$ Weight of moist soil + tin $(\mathrm{g})$

$\mathrm{W}_{3}=$ Weight of dried soil + tin $(\mathrm{g})$

The same procedure was repeated for salt samples using $5 \mathrm{~g}$ of the salt sample.

\subsubsection{Determination of Loss on Ignition (LoI)}

Triplicate samples of approximately $5 \mathrm{~g}$ oven-dried soil samples in silica crucibles were ignited in a muffle furnace for $16 \mathrm{~h}$ at $550{ }^{\circ} \mathrm{C}$ Crucibles were re-weighed after cooling and the $\%$ LOI was calculated.

\subsubsection{Determination of Cation Exchange Capacity, CEC, by Direct Method}

CEC is determined when $3 \mathrm{~g}$ of air dried soil ( $1 \mathrm{~g}$ peat) is leached with $60 \mathrm{~mL} 1 \mathrm{M} \mathrm{NH}_{4} \mathrm{OAc}, \mathrm{pH} \mathrm{7}$, to saturate exchange sites with ammonium ions. Excess free ammonium ions are rinsed from the soil with isopropyl alcohol. The remaining ammonium ions held on cation exchange sites are replaced by leaching the soil with successive aliquots of a solution of $10 \% \mathrm{KCl}$ acidified to $0.005 \mathrm{~N} \mathrm{HCl}$. Ammonium is determined on the $\mathrm{KCl}$ leachate by colorimetry on a Lachat QuikChem 8500 Flow Injection Analyzer using the salicylate/nitroprusside method.

\subsubsection{Determination of the Concentration of Iodine in Soil, Plant, Ash and Salt Samples}

Using an electronic analytical balance, (Shimadzu model AUY 120) 5 grams of the samples were weighed into $250 \mathrm{ml}$ beakers. The sample was digested for iodine analysis using the wet digestion method (Błażewicz, 2012; Yadata, 2014). The liberated iodine was titrated with 0.005 M Sodium thiosulphate solution using $1 \mathrm{ml}$ of $1 \%$ starch indicator near the end of the titration according to Ann (2012) and Lena, et $a l .$, (2015). The same procedure was repeated for dried plant samples, ash and salt samples for the determination of the concentration of iodine in plants, ash and salt samples respectively. From the redox reaction, based on the weight of the sample salt, $5 \mathrm{~g}$, used to prepare the salt solution, the 


\section{International Journal of Science and Research (IJSR) \\ ISSN (Online): 2319-7064 \\ Index Copernicus Value (2013): 6.14 | Impact Factor (2015): 6.391}

iodate content was calculated in $\mathrm{mg}$ of iodate per $\mathrm{kg}$ of the salt (ppm).

Formation of iodine from the iodate in salt solution, equation 3 ;

$$
\begin{aligned}
I O^{-3}(a q)+5 I^{-} & (a q)+6 \mathrm{H}_{2} \mathrm{O}(a q) \\
& \rightarrow 3 \mathrm{I}_{2}(a q)+9 \mathrm{H}_{2} \mathrm{O}(l) 3
\end{aligned}
$$

Formation of triiodide and blue complex with starch, equation 4 ;

$$
I_{2}(a q)+I^{-} \rightarrow I^{3-}(a q)+\text { starch } \rightarrow \text { blue complex } 4
$$

Reduction of iodide with thiosulfate, equation 5;

(Blue solution) (Colourless)

$$
\begin{aligned}
I^{3-}(a q)+\text { starch } & +2 \mathrm{~S}_{2} \mathrm{O}_{3}^{2-}(a q) \\
\rightarrow & S_{4} \mathrm{O}_{6}^{2-}(a q)+3 I^{-}(a q) 5
\end{aligned}
$$

The overall reaction is presesnted in equation 6 below;

$$
\begin{gathered}
I^{-3}(a q)+5 I^{-}(a q)+6 \mathrm{H}_{3} \mathrm{O}^{+}(a q)+6 S_{2} \mathrm{O}_{3}^{2-}(a q) \\
\rightarrow 6 S_{4} \mathrm{O}_{6}^{2-}(a q)+6 I^{-}(a q) 6
\end{gathered}
$$

The overall reaction implies that one equivalent of iodate $\left(\mathrm{IO}^{3-}\right)$ reacts with 6 equivalents of thiosulfate. Therefore, in terms of iodate/iodine weight, one equivalent of thiosulfate means 35.667 grams of potassium iodate $\left(\mathrm{FW} \mathrm{KIO}_{3} / 6\right.$ $=214 / 6=35.667)$, or 21.222 grams of iodine, knowing that potassium iodate contains $59.5 \%$ iodine $(35.667 \times 0.595$ $=21.222$ ).

The amount of iodate present in the samples is determined by redox titration using sodium thiosulfate solution, by first reacting the iodate $\left(\mathrm{IO}_{3}^{-}\right)$with added iodide $\left(\mathrm{I}^{-}\right)$, under acid conditions to produce iodine, equation 7 :

$$
\mathrm{IO}^{-3}+\mathrm{I}^{-}+6 \mathrm{H}+\rightarrow 3 \mathrm{I}_{2}+3 \mathrm{H}_{2} \mathrm{O} 7
$$

The resulting iodine which is highly soluble is titrated with $0.002 \mathrm{~mol} \mathrm{~L}^{-1}$ thiosulfate using $0.5 \%$ starch indicator solution as end-point indicator until the yellow/brown color of iodine becomes pale, equation 8 :

$3 I_{2}+2 S_{2} O_{3}^{2-} \rightarrow 2 I^{-}+S_{4} O_{6}^{2-} 8$

\subsubsection{Determination of $\mathrm{Na}$ and $\mathrm{K}$ metals in Soil, Plant, Ash and Salt samples}

5 grams of the sieved soil samples, plant, ash and salt samples were digested for $\mathrm{K}$ and $\mathrm{Na}$ analysis using the wet digestion method i.e 1:2 ratio of $10 \mathrm{ml}$ of $1: 1 \mathrm{HNO}_{3}$ and 20 $\mathrm{ml}$ of $1: 4 \mathrm{HCl}$, for 30 minutes hot plate until the production of red $\mathrm{NO}_{2}$ fumes had ceased. The digested samples were filtered using a Whatman No. 1 filter paper and filtrate made to $50 \mathrm{ml}$ mark and kept for analysis. The concentrations of $\mathrm{Na}$ and $\mathrm{K}$ in soil, plant and ash digests were determined spectrophotometrically, using a corning flame photometer, Corning model 410.

\subsubsection{Determination of Iron (II) content in salt samples}

Phenanthroline method was used for determination of iron (II) in the salt samples (Lipson et al., 2010). A UV-VIS spectrophotometer, single beam, Nova spec II model was used, at a wavelength of maximum absorbance, $\lambda_{\max }=508$ $\mathrm{nm}$. A series of standard ferrous ion solutions corresponding to $0.1,0.2,03,0.5,1.0,1.5$ and $2.0 \mathrm{ppm}$ respectively were used. The concentration of the samples was determined with the help of the calibration curve.

\subsection{Method Validation}

\subsubsection{Analytical wavelength $(\mathrm{nm})$, detection limits $(\mu \mathrm{g} / \mathrm{mL})$ and regression data.}

The analytical wavelength $(\mathrm{nm})$, detection limits $(\mathrm{mg} / \mathrm{kg})$, regression equation and correlation coefficient are presented in Error! Reference source not found.. The results indicate that linearity for all trace elements was good, with correlation coefficient $\geq 0.9998$. Detection limits ranged from 0.0005 to $0.0100 \mathrm{mg} / \mathrm{kg}$.

\subsubsection{Accuracy and Precision}

In order to verify the accuracy and precision of the method, reed samples were randomly chosen to evaluate the precision of method $(n=6)$ and the results were given in (Error! Reference source not found.). The results indicate good precision under the analytical conditions used since the relative standard deviations were $<5 \%$ and the method was precise.

\subsubsection{Recovery of developed method}

A recovery work was carried out to demonstrate the validity of the method. Cyperus papyrus reed salt was selected to detect the recovery through quantity added. Cyperus papyrus reed salt samples were prepared and determined using the recommended procedure. From Error! Reference source not found., the results were considered satisfactory because recovery ranged from 91 to $102.0 \%$.

\subsubsection{Statistical analysis}

The data were based on three replicates and subjected to analysis of variance. Statistical analysis was done using SAS, GENSTAT and SPSS 21.0 (SPSS Inc., Chicago, IL, USA). Means were calculated and compared using t-test, standard errors of each individual nutrient of the samples were computed, and variations among the species were evaluated by least significance difference (LSD) at $5 \%$ level of probability $(\mathrm{p}<0.05)$. A Randomized Completely Block Design with Analysis of covariance (ANOVA) was done for nutrients iodine, iron, magnesium, potassium and sodium and mean separation done by Fischers protected LSD for significance. A multivariate comparison of means as well as Regression was done to establish each independent variable's contribution to the change in elemental contents of the salts. Correlation was done to establish the relationship between soil-plant-salt elemental concentrations.

\subsection{Results}

1.6.1 Results of Soil pH, Bulk density, texture and average loss on ignition

Error! Reference source not found, gives results of selected soil properties $\mathrm{pH}, \%$ moisture, \% nitrogen, CEC, soil texture, LOI, phosphorus content and SBD for soil slurries and soil collected from Busia's swamp and the banks of River Nzoia respectively. The soil $\mathrm{pH}$, texture, bulk density and average loss on ignition at depth, $0-15 \mathrm{~cm}$ and $15-30 \mathrm{~cm}$ respectively, were measured in the samples. 


\section{International Journal of Science and Research (IJSR) \\ ISSN (Online): 2319-7064}

Index Copernicus Value (2013): 6.14 | Impact Factor (2015): 6.391

Table 1: Selected soil Properties of Busia and Lugari Soils.

\begin{tabular}{|l|c|c|c|c|c|}
\hline Sampling area & Ululo & Bidimbidi & Lugari & Matete & cv \\
\hline $\mathrm{pH}$ & $6.4 \pm 0.01^{\mathrm{a}}$ & $6.2 \pm 0.03^{\mathrm{b}}$ & $6.3 \pm 0.01^{\mathrm{c}}$ & $4.9 \pm 0.02^{\mathrm{d}}$ & 1.2 \\
\hline \% moisture & $57.5 \pm 0.03^{\mathrm{a}}$ & $66.5 \pm 0.07^{\mathrm{b}}$ & $42.2 \pm 0.20^{\mathrm{c}}$ & $22.2 \pm 0.02^{\mathrm{d}}$ & 0.1 \\
\hline \% N & $0.3 \pm 0.01^{\mathrm{a}}$ & $0.3 \pm 0.002^{\mathrm{b}}$ & $0.2 \pm 0.01^{\mathrm{a}}$ & $0.2 \pm 0.01^{\mathrm{b}}$ & 27.4 \\
\hline $\mathrm{CEC} \mathrm{meq} / 100 \mathrm{~g}$ & $165.0 \pm 15.0^{\mathrm{a}}$ & $91.0 \pm 1.00^{\mathrm{b}}$ & $92.0 \pm 2.00^{\mathrm{c}}$ & $86.8 \pm 0.11^{\mathrm{d}}$ & 0.1 \\
\hline SBD, g/cm3 & $0.3 \pm 0.01^{\mathrm{a}}$ & $0.3 \pm 0.02^{\mathrm{b}}$ & $0.3 \pm 0.01^{\mathrm{c}}$ & $0.3 \pm 0.01^{\mathrm{d}}$ & 0.1 \\
\hline \% clay & $23.8 \pm 3.80^{\mathrm{a}}$ & $18.9 \pm 0.93^{\mathrm{b}}$ & $10.5 \pm 0.50^{\mathrm{c}}$ & $11.0 \pm 1.00^{\mathrm{d}}$ & 0.4 \\
\hline \% sand & $70.3 \pm 9.30^{\mathrm{a}}$ & $60.9 \pm 0.05^{\mathrm{b}}$ & $88.8 \pm 0.15^{\mathrm{c}}$ & $88.9 \pm 0.28^{\mathrm{d}}$ & 0.1 \\
\hline \% silt & $5.9 \pm 5.50^{\mathrm{a}}$ & $19.6 \pm 0.20^{\mathrm{b}}$ & $1.5 \pm 0.09^{\mathrm{c}}$ & $1.4 \pm 0.02^{\mathrm{d}}$ & 1.0 \\
\hline \% LOI & $59.3 \pm 4.30^{\mathrm{a}}$ & $61.0 \pm 1.00^{\mathrm{b}}$ & $41.5 \pm 0.50^{\mathrm{c}}$ & $42.5 \pm 0.50^{\mathrm{d}}$ & 0.1 \\
\hline P, mg/kg & $16.7 \pm 0.79^{\mathrm{a}}$ & $12.3 \pm 0.01^{\mathrm{b}}$ & $18.3 \pm 5.79^{\mathrm{c}}$ & $6.7 \pm 5.79^{\mathrm{d}}$ & 0.5 \\
\hline
\end{tabular}

Results are expressed as means \pm standard error of the mean (MSE) for 3 determinations. Within rows, means with different alphabets are statistically different at $\mathrm{p}<0.05$ by ANOVA and LSD test. $n=12$, $1 \mathrm{sd}=0.0836$; s.e. $\mathrm{d}=0.0396$;
1.6.2 Concentration of Iodine, $\mathrm{K}$ and $\mathrm{Na}$ in Soils and Plants Samples

The level of micronutrients (Iodine, $\mathrm{Na}, \mathrm{K}$ and $\mathrm{Fe}$ ) were determined in various soil and plant samples collected in Busia and Lugari regions of Western Kenya are presented in

Table

2

and

Table 3respectively.

Table 2: The concentrations of K, Na and Iodine soil samples collected during the dry and wet seasons from Busia and Lugari Regions at varying depths

\begin{tabular}{|c|c|c|c|c|c|c|c|c|}
\hline \multirow[b]{3}{*}{ sampling area } & \multirow[b]{3}{*}{ depth $\mathrm{cm}$} & \multicolumn{4}{|c|}{ DRY SEASON } & \multicolumn{3}{|c|}{ WET SEASON } \\
\hline & & \multicolumn{7}{|c|}{ Concentration, $\mathrm{mg} / \mathrm{kg}$} \\
\hline & & $\mathrm{pH}$ & $\mathrm{K}$ & Iodine & $\mathrm{Na}$ & $\mathrm{pH}$ & $\mathrm{K}$ & $\mathrm{Na}$ \\
\hline \multirow[t]{2}{*}{ Ululo } & $0-15 \mathrm{~cm}$ & $6.5 \pm 0.34$ & $640.3 \pm 19.85$ & $208.8 \pm 0.95$ & $1671.1 \pm 24.05$ & $6.9 \pm 0.02$ & $269.9 \pm 8.24$ & $2025.3 \pm 6.25$ \\
\hline & $15-30 \mathrm{~cm}$ & $6.4 \pm 0.41$ & $560.9 \pm 19.85$ & $124.0 \pm 1.16$ & $897.3 \pm 0.001$ & $6.8 \pm 0.03$ & $262.6 \pm 0.69$ & $1562.8 \pm 2.25$ \\
\hline \multirow[t]{2}{*}{ Bidimbidi } & $0-15 \mathrm{~cm}$ & $6.2 \pm 0.73$ & $680.0 \pm 13.23$ & $170.3 \pm 5.72$ & $850.6 \pm 13.34$ & $6.9 \pm 0.01$ & $274.0 \pm 2.83$ & $1011.0 \pm 0.50$ \\
\hline & $15-30 \mathrm{~cm}$ & $6.1 \pm 0.67$ & $349.2 \pm 19.84$ & $112.7 \pm 7.34$ & $470.3 \pm 6.67$ & $6.7 \pm 0.01$ & $272.7 \pm 4.22$ & $1123.8 \pm 13.75$ \\
\hline \multirow[t]{2}{*}{ Matete } & $0-15 \mathrm{~cm}$ & $6.3 \pm 0.51$ & $964.4 \pm 20.92$ & $139.6 \pm 9.15$ & $603.7 \pm 42.19$ & $7.1 \pm 0.02$ & $266.8 \pm 6.46$ & $1060.5 \pm 7.00$ \\
\hline & $15-30 \mathrm{~cm}$ & $6.3 \pm 0.50$ & $640.3 \pm 159.76$ & $107.1 \pm 4.22$ & $640.4 \pm 61.67$ & $7.1 \pm 0.03$ & $267.7 \pm 7.31$ & $1064.8 \pm 11.25$ \\
\hline \multirow[t]{2}{*}{ Lugari } & $0-15 \mathrm{~cm}$ & $6.1 \pm 0.01$ & $964.4 \pm 33.08$ & $86.4 \pm 0.56$ & $510.3 \pm 6.68$ & $6.9 \pm 0.02$ & $260.4 \pm 0.02$ & $1248.5 \pm 3.8$ \\
\hline & $15-30$ & $4.3 \pm 0.02$ & $865.2 \pm 33.08$ & $91.1 \pm 1.11$ & $470.3 \pm 6.67$ & $4.8 \pm 1.02$ & $0.25 \pm 0.10$ & $24.25 \pm 3.08$ \\
\hline
\end{tabular}

Results are expressed as means \pm standard error of the mean (MSE) for 3 determinations; statistically different at $\mathrm{p}<0.05$ by ANOVA and LSD test. $\mathrm{n}=12$

Table 3: K, Na and Iodine concentrations in plants from Busia and Lugari regions sampled during the dry and wet season, at $95.0 \%$ confidence level.

\begin{tabular}{|c|c|c|c|c|c|c|}
\hline \multirow{2}{*}{ Sampling Point } & \multicolumn{2}{|c|}{ Concentration, $\mathrm{mg} / \mathrm{kg}$ for the wet season } & \multicolumn{3}{c|}{ Concentration, mg/kg for the dry season } \\
\cline { 2 - 7 } & Iodine & $\mathrm{K}$ & $\mathrm{Na}$ & \multicolumn{2}{c|}{ Iodine } & $\mathrm{Na}$ \\
\hline Ululo & $21.4 \pm 5.19$ & $3279.8 \pm 9.23$ & $286.8 \pm 19.85$ & $21.2 \pm 5.64$ & $442.5 \pm 4.80$ & $8677.7 \pm 7.83$ \\
\hline Bidimbidi & $22.0 \pm 2.00$ & $2055.9 \pm 66.15$ & $783.8 \pm 13.34$ & $36.8 \pm 3.58$ & $292.1 \pm 5.81$ & $4024.5 \pm 18.05$ \\
\hline Matete & $27.6 \pm 3.83$ & $2452.9 \pm 11.79$ & $1235.3 \pm 12.15$ & $23.8 \pm 3.05$ & $209.6 \pm 4.42$ & $1767.3 \pm 9.72$ \\
\hline Lugari & $7.8 \pm 5.63$ & $2618.2 \pm 60.99$ & $1360.9 \pm 9.06$ & $4.2 \pm 0.14$ & $263.1 \pm 0.002$ & $1085.7 \pm 7.43$ \\
\hline
\end{tabular}

Results are expressed as means \pm standard error of the mean (MSE) for 3 determinations; statistically different at $\mathrm{p}<0.05$ by ANOVA and LSD test. $n=12$
1.6.4 pH, Moisture, and concentration of Micronutrients (iodine, $\mathrm{Na}, \mathrm{K}$ ) in Salt Samples.

Salt samples were analysed for $\mathrm{pH}$, micronutrients and the heavy metals and the findings are represented in

Table 4 for the wet and dry seasons respectively. 
Table 4: Concentration of Micronutrients iodine, $\mathrm{Na}, \mathrm{K}$ and $\mathrm{Fe}^{2+}$ in Salt Samples for the wet and dry seasons

\begin{tabular}{|c|c|c|c|c|c|c|c|}
\hline Dry season & \multicolumn{2}{|l|}{ Sampling area } & $\mathrm{pH}$ & $\%$ Moisture & iodine & $\mathrm{Fe}^{2+}$ & $\mathrm{Na}$ \\
\hline & \multicolumn{2}{|l|}{ Lugari } & $9.7 \pm 0.21$ & $0.5 \pm 0.21$ & $1.2 \pm 0.50$ & $1.1 \pm 0.001$ & $3398.4 \pm 43.28$ \\
\hline & \multicolumn{2}{|l|}{ Matete } & $9.8 \pm 0.01$ & $1 \pm 0.05$ & $1.4 \pm 0.60$ & $1.0 \pm 0.002$ & $5957.2 \pm 24.00$ \\
\hline & \multicolumn{2}{|l|}{ Ululo } & $10.4 \pm 0.10$ & $8.2 \pm 1.80$ & $0.2 \pm 0.10$ & $1.0 \pm 0.00$ & $12650.1 \pm 47.09$ \\
\hline & \multicolumn{2}{|l|}{ Bidimbidi } & $10.0 \pm 0.30$ & $15.6 \pm 0.001$ & $1.6 \pm 0.90$ & $1.0 \pm 0.002$ & $15752 \pm 46.60$ \\
\hline \multirow[t]{12}{*}{ Wet season } & Sampling area & $\mathrm{pH}$ & $\%$ Moisture & iodine & $\mathrm{Fe}^{2+}$ & $\mathrm{Na}$ & $\mathrm{K}$ \\
\hline & Lugari & 9.7 & $0.5 \pm 0.25$ & $1.3 \pm 0.65$ & $1.1 \pm 0.01$ & $3016.8 \pm 73.39$ & $4305.2 \pm 8.75$ \\
\hline & Matete & 9.8 & $1.0 \pm 0.05$ & $0.6 \pm 0.28$ & $1.0 \pm 0.01$ & $3403.3 \pm 9.12$ & $4966.7 \pm 59.36$ \\
\hline & Ululo & 10.2 & $8.7 \pm 1.52$ & $1.6 \pm 0.79$ & $1.0 \pm 0.01$ & $9081.9 \pm 26.41$ & $3114.4 \pm 36.38$ \\
\hline & Bidimbidi & 10.5 & $15.6 \pm 4.27$ & $0.1 \pm 0.01$ & $1.0 \pm 0.01$ & $10419.2 \pm 29.35$ & $3809.0 \pm 87.51$ \\
\hline & Ululo & 10.6 & $11.2 \pm 0.22$ & $2.1 \pm 1.06$ & $1.0 \pm 0.03$ & $10125.6 \pm 6.13$ & $3974.4 \pm 6.45$ \\
\hline & Ululo & 10.5 & $4.9 \pm 0.34$ & $2.1 \pm 0.65$ & $1.0 \pm 0.01$ & $9929.9 \pm 10.93$ & $3809.0 \pm 7.56$ \\
\hline & Bidimbidi & 9.6 & $15.9 \pm 2.87$ & $0.4 \pm 0.24$ & $1.1 \pm 0.01$ & $10517.0 \pm 159.79$ & $3974.4 \pm 86.45$ \\
\hline & Lugari & 9.7 & $0.5 \pm 0.25$ & $1.3 \pm 0.70$ & $1.1 \pm 0.01$ & $3016.8 \pm 73.40$ & $4305.2 \pm 75.10$ \\
\hline & Matete & 9.8 & $1.0 \pm 0.21$ & $0.6 \pm 0.30$ & $1.0 \pm 0.01$ & $3403.3 \pm 9.10$ & $4966.7 \pm 9.40$ \\
\hline & Ululo & $10.4 \pm 0.10$ & $8.2 \pm 1.80$ & $1.9 \pm 0.40$ & $1.0 \pm 0.01$ & $9636.5 \pm 40.34$ & $3632.6 \pm 26.20$ \\
\hline & Bidimbidi & $10.0 \pm 0.30$ & $15.6 \pm 0.01$ & $0.2 \pm 0.10$ & $1.0 \pm 0.03$ & $10468.3 \pm 15.58$ & $3891.7 \pm 13.50$ \\
\hline
\end{tabular}

Results are expressed as means \pm standard error of the mean (MSE) for 3 determinations; statistically different at $\mathrm{p}<0.05$ by ANOVA and LSD test. $\mathrm{n}=12$;

\subsubsection{Comparison of Micronutrients for Reeds and Commercial Salts}

Results for reed salts were compared with commercial salts obtained from the supermarket. A total of four types of commercially available table salts were analysed for essential and non-essential elements and micronutrients,

The results are presented in table below

Table 5: Comparison of Typha latifolia salt, Cyperus papyrus Salt and Commercial Salts

\begin{tabular}{|c|c|c|c|c|c|c|}
\hline \multirow[b]{3}{*}{ Element } & \multicolumn{6}{|c|}{ Type of salt } \\
\hline & T. latifolia salt & C. papyrus salt & HSSA & SSSA & KNSA & TCSA \\
\hline & \multicolumn{6}{|c|}{ Concentration, $\mathrm{mg} / \mathrm{kg}$} \\
\hline iodine & $1.1 \pm 0.18$ & $0.9 \pm 0.31$ & $19.5 \pm 4.79$ & $7.4 \pm 0.89$ & $95.6 \pm 1.20$ & $69.4 \pm 2.39$ \\
\hline $\mathrm{Fe}^{2+}$ & $1.0 \pm 0.01$ & $1.0 \pm 0.001$ & $2.3 \pm 0.03$ & $0.2 \pm 0.03$ & ND & ND \\
\hline $\mathrm{Mg}$ & $52.5 \pm 3.22$ & $29.2 \pm 1.49$ & $156.5 \pm 4.48$ & $48.1 \pm 0.17$ & $38.9 \pm 0.17$ & $15.4 \pm 3.45$ \\
\hline $\mathrm{Na}$ & $3943.8 \pm 7.34$ & $9969.2 \pm 0.01$ & $20099.6 \pm 33.54$ & $21285.6 \pm 77.20$ & $18913.6 \pm 59.07$ & $23855.1 \pm 33.94$ \\
\hline $\mathrm{K}$ & $4635.8 \pm 0.01$ & $8813.5 \pm 7.33$ & $10047.0 \pm 13.4$ & $3819.0 \pm 0.01$ & $4294 \pm 67.19$ & $4769.0 \pm 0.01$ \\
\hline$\%$ Ratio of salt & 4.0 & 0.003 & & & & \\
\hline$\%$ Ratio of salt to raw material & 10.0 & 0.125 & & & & \\
\hline
\end{tabular}

Results are expressed as means \pm standard error of the mean (MSE) for 3 determinations; statistically different at $\mathrm{p}<0.05$ by ANOVA and LSD test. $\mathrm{n}=12$; ND= Not detected; HSSA= herbal sea salt; SSSA; KNSA= Kensalt; TCSA=Top Chef salt.

\subsubsection{Soil-plant transfer coefficient or Bio-accumulation Factor (BAF)}

In the present study, the Transfer factors for different heavy metal from soil to reed plants, calculated from equation 3 (section 2.3.4) are presented in Table 6.

Table 6: Transfer factor of micronutrients from soils into reed samples

\begin{tabular}{|c|c|c|c|c|}
\hline Transfer factors for respective elements & & & & \\
\hline Element/sampling point & Iodine & $\mathrm{K}$ & $\mathrm{Na}$ & $\mathrm{Mg}$ \\
\hline BRPU & 0.128 & 4.294 & 2.912 & 1.159 \\
\hline BRPB & 0.208 & 2.980 & 2.783 & 1.047 \\
\hline LRPM & 0.208 & 2.489 & 1.782 & 1.935 \\
\hline
\end{tabular}




\section{International Journal of Science and Research (IJSR)}

ISSN (Online): 2319-7064

Index Copernicus Value (2013): 6.14 | Impact Factor (2015): 6.391

Results are expressed as means \pm standard error of the mean (MSE) for 3 determinations; statistically different at $\mathrm{p}<0.05$ by ANOVA and LSD test. $n=12$

\subsubsection{Estimation of the dietary intake of the selected metals (EDIM)}

In the present study, estimation of the dietary intake of the selected metals was calculated from and the results are presented

Table 7.

Table 7: Estimation of the dietary intake of the selected metals (EDIM) and the permissible limits

\begin{tabular}{|c|c|c|c|c|c|c|c|c|}
\hline & \multicolumn{2}{|c|}{ Mean conc. $\mathrm{Mg} / \mathrm{kg}$} & $\mathrm{DI}$ & & PTWs & & EDIM & \\
\hline Plant species & $\mathrm{Na}$ & $\mathrm{K}$ & $\mathrm{Na}$ & $\mathrm{K}$ & $\mathrm{Na}$ & $\mathrm{K}$ & $\mathrm{Na}$ & $\mathrm{K}$ \\
\hline Typha latifolia & 3732 & 3734 & 18660 & 18670 & 130619 & 130689 & 311 & 311 \\
\hline Cyperus papyrus & 13101 & 2762 & 65507 & 13811 & 458547 & 96679 & 1092 & 230 \\
\hline HSSA & 20100 & 10047 & 100498 & 5235 & 703486 & 36646 & 1675 & 87 \\
\hline SSSA & 21286 & 3819 & 106428 & 1910 & 744994 & 13367 & 1774 & 32 \\
\hline KNSA & 18914 & 4294 & 94568 & 2147 & 661977 & 15029 & 1576 & 36 \\
\hline TCSA & 23855 & 4769 & 119276 & 2385 & 834930 & 16692 & 1988 & 40 \\
\hline Permissible limits & & & $2300 \mathrm{mg} /$ dy & $3500 \mathrm{mg} /$ dy & & & & \\
\hline
\end{tabular}

${ }^{\text {a }}$ WHO/FAO (1999); ${ }^{b} \mathrm{WHO} / \mathrm{FAO}$ Kihampa et al (2011);HSSA- Herbal salt; TCSA - Top-chef table salt; KNSA - Kensalt; SSSA - Sea salt naturals;

\subsection{Discussion}

\subsubsection{Selected properties of soil samples}

According to the classification of soils on the basis of $\mathrm{pH}$ (1:5 soil: water), both Cyperus P. and Typha L. reeds of Lugari and Busia regions respectively, grow in weak acidic soils of $\mathrm{pH}$ range from 4.9-6.5, (Error! Reference source not found.). The $\mathrm{pH}$ values are in the range of $6.2-6.4$ with a mean of 6.3 for Busia soils and 4.9-6.3 with a mean of 5.6 for Lugari soils, implying that Busia soils are weakly acidic compared to Lugari soils that are more acidic, although both have an average $\mathrm{pH}$ of 6.0. The $\mathrm{pH}$ of Busia soil in both sampling points, Ululo (6.5) and Bidimbidi (6.2), was higher than that in Matete (4.9), but almost the same with Lugari (6.3) in Lugari's region. This could probably be due to the presence of the swamps mulching effect and also to the dilution effect during the wet season. From appendix 6, it is clear that $\mathrm{pH}$ is dependent on season, depth and location of

Table 1. The \% CEC is dependent on \% clay and SBD ( $\mathrm{p}_{\text {values }}$ of 0.021 and $0.049<0.05$ ) and positively contributes to the CEC in soil (coeff 3.39 and -3532 respectively), App. 32. Busia soils on the other hand, had a bulk density of $0.316-0.322 \mathrm{~g} / \mathrm{cm}^{3}$ with a moisture content of 57.5-66.5\%, while the organic matter content indicated by loss on ignition (LOI) was 59.3-61\%. Lugari samples had a bulk density of $0.315-0.322 \mathrm{~g} / \mathrm{cm}^{3}$ with a moisture content of 22.2- $42.2 \%$ and LOI of 41.5-42.5\%. Organic matter content in Busia soils is higher than that of Lugari due to the presence of increased humus as a result of high plant material decomposition compared to Lugari region. sampling, $\mathrm{p}<.0001 . \mathrm{pH}$ dramatically affects the CEC of soil by limiting the available exchange sites at low $\mathrm{pH} . \mathrm{H}^{+}$bind to soil particles tighter than other cations, thus, any metal bound to a soil particle will get booted off in the presence of excess $\mathrm{H}^{+}$. At low $\mathrm{pH}(<6), \mathrm{H}^{+}$is in excess and replaces all other cations on the micelle, thus making them bioavailable. At high $\mathrm{pH}(>7)$, cations are less bioavailable because they have less competition from $\mathrm{H}^{+}$for available binding sites. Many cations bind to free hydroxyl groups $\left(\mathrm{OH}^{-}\right)$and form insoluble hydrous metal oxides, which are unavailable for uptake, such as $\mathrm{CdCO}_{3}$.

Sand and clay fractions were dominant in both the two regions.Busia soils are sandy loam soils with a texture of a mean range of $18.9-23.8 \%$ clay, $5.9-19.6 \%$ silt and 60.9 $70.3 \%$ sand; Lugari soils are sandy loam with $10.5-11.0 \%$ clay, $1.4-1.5 \%$ silt and $88.8-88.9 \%$ sand; classified as Typic Xerofluvent (American Soil Taxonomy),

The results indicate that LOI or organic matter content is a function of $\%$ moisture $\left(p_{\text {value }}=0.001\right.$, coeff. $\left.=0.455\right), \%$ silt $\left(p_{\text {value }}=0.002\right.$, coeff 1.00$)$ and $\%$ clay $\left(p_{\text {value }}=563 \mathrm{E}-07\right.$, coeff $1.40)$ which have a $p_{\text {value }}<0.05$ (

Appendix 4). The higher the \% clay content of the soil, the higher the soil organic matter, and therefore higher LOI which agrees with Skaven-Haug (1972). Results of the soils under investigation agree with the previous studies where Skaven-Haug (1972) indicated values of 0.4-1.3 percent for sand and silt and values of 3.9-6.0 \% for very fine clay material. This peat, with a Busia and Lugari soils had slightly higher BD than Tie and Kueh (1979) results (LOI of 


\section{International Journal of Science and Research (IJSR) \\ ISSN (Online): 2319-7064 \\ Index Copernicus Value (2013): 6.14 | Impact Factor (2015): 6.391}

95 percent, had bulk densities of 0.15 and $0.13 \mathrm{~g} / \mathrm{cm}^{3}$ at depths of $0-15$ and $15-30 \mathrm{~cm}$ respectively), implying that these pits are less decomposed and hence the high BD and lowered LOI due to less OM presence. Equally they have a similar trend with higher silt than sand and clay, for sandy loamy soils, although Lugari soils are sandier than Busia samples. The similarity can also be noted in the moisture and LOI which shows that soil texture is dependent on moisture and LOI (organic matter). This is because of the swampy organic rich Busia soils than the Lugari river sediments and or river bank soils with less organic matter for ignition. In this study findings soils in Lugari are more sandy than Busia soils, with a lower BD than that recommended for sandy soils by Grossman (2002), the soil is therefore ideal for root growth. This is also due to increased organic matter accumulation and decomposition rates, evapotranspiration and lateral flow deposition (Tsheboeng et al., 2014).

\subsubsection{Ash and Salt's Selected Properties}

The $\mathrm{pH}$ of Busia's Cyperus papyrus salt samples had higher $\mathrm{pH}$ values, with an average of 10.53 ranging from 10.23 to 10.55, while Lugari's Typha latifolia salt sampleshad an average of 9.66 with a range of 9.56 to 9.76, (Error!

\section{Table 4)}

From literature, salt contents of plants are generally low. $C$. papyrus contains higher $\%$ ratio of salt to ash and to the raw material, $10 \%$ for ash and $0.125 \%$ for raw material, more than that for T. latifolia with $4 \%$ of salt in the ash obtained and $0.003 \%$ of the raw material. The lowest ratio of salt in reed stems can be explained by the fact that they contain essentially carbohydrates like cellulose which burn in processing for ash production. The high percentage of salt from $C$. papyrus explains why it's still the most traditionally used plant in Busia region to produce indigenous salt. Most of the authors have found the ratio of $0.42 \%$ of raw fern, $0.55 \%$ of raw vine, $0.55 \%$ of raw willow and $0.15 \%$ of raw oak (East African Community, 2011). All these data are lower than 1.0 just as the results obtained in this study. It is evident from the regression results that the \% CEC increases ten-fold for every one parts increase of \% LOI $\left(\mathrm{p}_{\text {value }}=0.0036\right.$, coeff $\left.=10.77\right)$,
Reference source not found.). This was expected due to the high $\mathrm{K}$ and $\mathrm{Na}$ concentrations given in (Error! Reference source not found.). Cyperus papyrus salts reported a mean $\%$ moisture content of $10.08 \%$ compared to Typha latifolia salts with 0.73. Salts from Cyperus papyrus species of Busia County had the highest moisture content, ranging from 4.88 $\%$ to $15.61 \%$ with the highest $15.61 \%$ having been obtained from Bidimbidi village, while those from Lugari County, Typha latifolia salts had the lowest moisture content with a range of $0.53 \%$ to $1.03 \%$, the highest $1.03 \%$ coming from Matete division, Error! Reference source not found.. Salts obtained from Cyperus papyrus reed plants that thrive in swampy areas have higher moisture contents than those from Typha Latifolia. When determined in accordance with ISO 2483, the moisture content of food grade salt shall not be greater than $0.5 \%$ by mass, Lugari samples meet this specification, however, Busia salt has high \% moisture content than the recommended one (East African Community, 2013). Evaporation-crystallisation method used in Busia tends to retain more moisture than the one for Lugari region

Appendix 4 and Appendix 7.

1.7.3 Concentration of Iodine, $\mathrm{Na}, \mathrm{K}$ and $\mathrm{Fe}^{2+}$ in Soil

Findings of this study indicate that an increase in $\mathrm{Na}$ leads to a decrease in $\mathrm{K}(\mathrm{r}=-0.5815)$ as well as iodine (

Appendix 7), which also decreases with depth supported by the regression values, shows the concentration of iodine, $\mathrm{Na}$ and $\mathrm{K}$ decreased with depth which is in agreement with Whitehead (1978) probably due to soil water dilution and increased leaching as water infiltrates the soil leading to leaching of cations. A positive relation between the concentration $\mathrm{K}$ and $\mathrm{Mg}$ ( $\mathrm{p}_{\text {value }}$ of $0.0157<.0 .05$ and coeff of 0.0184 ) and the $\mathrm{pH}$ were observed while that of iodine had a negative relation. For instance, at $\mathrm{pH} 4.32$ the concentration of $\mathrm{Mg}$ is $242.49 \mathrm{mg} / \mathrm{kg}$ while at a $\mathrm{pH}$ of 6.38 their concentrations are $250.57 \mathrm{mg} / \mathrm{kg}$. An increase in $\mathrm{K}$ implies an increase of about $2 \%$ in $\mathrm{Mg}$ concentration as soil iodine decreases as supported from the value obtained for the correlation coefficient of -0.6521 (

\section{Appendix 4 and}

Appendix 7). These elements tend to complement each other chemically. The concentration of $\mathrm{Na}$ was found to decrease with increase in $\%$ LOI $\left(p_{\text {value }}=0.040\right.$, coeff $\left.=-123.7\right)$ but with a decrease in $\%$ clay $\left(p_{\text {value }}=0.0275\right.$, coeff $\left.=226.11\right)$. Equally an increase in $\mathrm{Na}$ was observed when the concentration of $\mathrm{Cr}$ decreased ( $\mathrm{p}_{\text {value }}=0.0361$, coeff $=-16.74$ ). There is exchange of ions in the soil through chemical interaction and since $\mathrm{Na}$ is higher in reactivity than $\mathrm{Cr}$ it is expected that they exchange sites thereby creating this relationship. Results of this study also reveal that the 


\section{International Journal of Science and Research (IJSR) \\ ISSN (Online): 2319-7064 \\ Index Copernicus Value (2013): 6.14 | Impact Factor (2015): 6.391}

concentration of $\mathrm{K}$ is linearly related to $\mathrm{pH}, \%$ moisture, $\%$ clay, $\mathrm{Fe}$, and $\mathrm{Mg}$ while it is inversely proportional to $\% \mathrm{~N}$, CEC, \% sand, \% silt, SBD, \% LOI, P, and $\mathrm{Pb}$. However, it is not affected by the increase or decrease of $\mathrm{Cd}$ and $\mathrm{Cr}$ whose $\mathrm{p}_{\text {values }}$ are greater than 0.05 (

\section{Appendix 4 and \\ Appendix 7).}

Top soils, 0-15 cm, contained higher iron and iodine contents than sub-soils 15-30 cm deep (Error! Reference source not found.). The presence of high organic matter content (LOI) and the implication that the humus level is higher may have contributed to the assimilation of iodine in the top soil which constitutes the primary reservoir of iodine in most soils. Equally, Metal oxides and hydroxides like $\mathrm{Fe}(\mathrm{OH})_{3}$ may play an important role in controlling iodine behavior in soils, both through adsorption of inorganic iodine and oxidation of iodide (Steinberg et al., 2008a, Steinberg et al., 2008c and Dai et al., 2009). The findings of this study agree with Fuge (2005) who showed that iodine is concentrated in iron-rich soils. Oxidation of $\mathrm{I}^{-}$to $\mathrm{I}_{2}$ and then to $\mathrm{IO}^{3-}$ has been shown to be a catalyzed reaction with $\mathrm{IO}^{3-}$ adsorbing on the metal surface (Gallard et al., 2009). In the presence of humic substances the oxidation to $\mathrm{IO}^{3-}$ is limited as $\mathrm{I}_{2}$ can react to form organic iodine (org-I) species, especially at lower pH (Gallard et al., 2009).

The results also show that the lower the moisture content the lower the iodine level (Error! Reference source not found.). Lugari samples have lower iodine concentrations than Busia which has high moisture and organic matter content. The high moisture is due to the high retention of water by the high organic matter present in Busia swamps. These levels are all higher from those found by Whitehead $(1978 ; 1979)$ in several UK soils that found a range of 0.5 to $98.2 \mathrm{mg} \mathrm{kg}^{-1}$ but agrees since they decreased vertically upto $30 \mathrm{~cm}$ in depth and with soil type. Yuita and Kihou (2005) also observed higher concentrations in topsoil of three Japanese soils compared to subsoil especially where the subsoil was more reducing, which agrees with the present findings. However, the present study had significant differences in iodine content in the soil samples analysed. The observed decrease in iodine concentrations with depth in a typical soil could alternatively be a result of reduction of weakly organic-bound iodine to iodide at low redox potentials resulting in the release of iodine from soils into the soil solution. There is a reductive release of soil iodine to soil solution in deep soil horizons agreeing with other studies (Yuita et al., 1991; Yuita and Kihou, 2005; Ashworth and Shaw, 2006; Yamaguchi et al., 2010). Equally, it was found that iodine increases with increase in SBD and \% clay $\left(\mathrm{p}_{\text {value }}=0.0199\right.$ and 0.0229 with coeff of 5650 and 17.25 respectively) since Iodine adsorbs strongly on clay matter (

\section{Appendix 4).}

Strong correlations were found between soil iodine, Fe and $\mathrm{Na}$. There was a linear proportionality between iron and iodine since an increase in iodine caused an increase in iron. Soil metal oxides have been shown to oxidize iodide in amounts proportional to their concentration, and inversely proportional to $\mathrm{pH}$, in a reaction that is thermodynamically favorable up to pH 7.5 (Allard et al., 2009 and Gallard et al., 2009). The ultimate fate of iodine in soil appears to be incorporation into solid phase humus via formation of intermediates e.g. HOI or $\mathrm{I}_{2}$. Abiotic reduction of $\mathrm{IO}^{3-}$, or oxidation of $\mathrm{I}^{-}$by solid or aqueous organic matter are likely to be the main mechanisms by which these intermediates are formed as the reaction rates observed appear to be too fast for biological processes to play a significant role. Soil $\mathrm{pH}$ acts mainly on the initial adsorption of iodate while soil humus appears to control time-dependent sorption. This was further attributed to the scavenging characteristics of soil metal oxyhydroxides for inorganic iodine forms (Dai et al., 2004; Um et al., 2004). The highest iodine concentrations were associated predominantly with iron content rather than with soil organic matter.

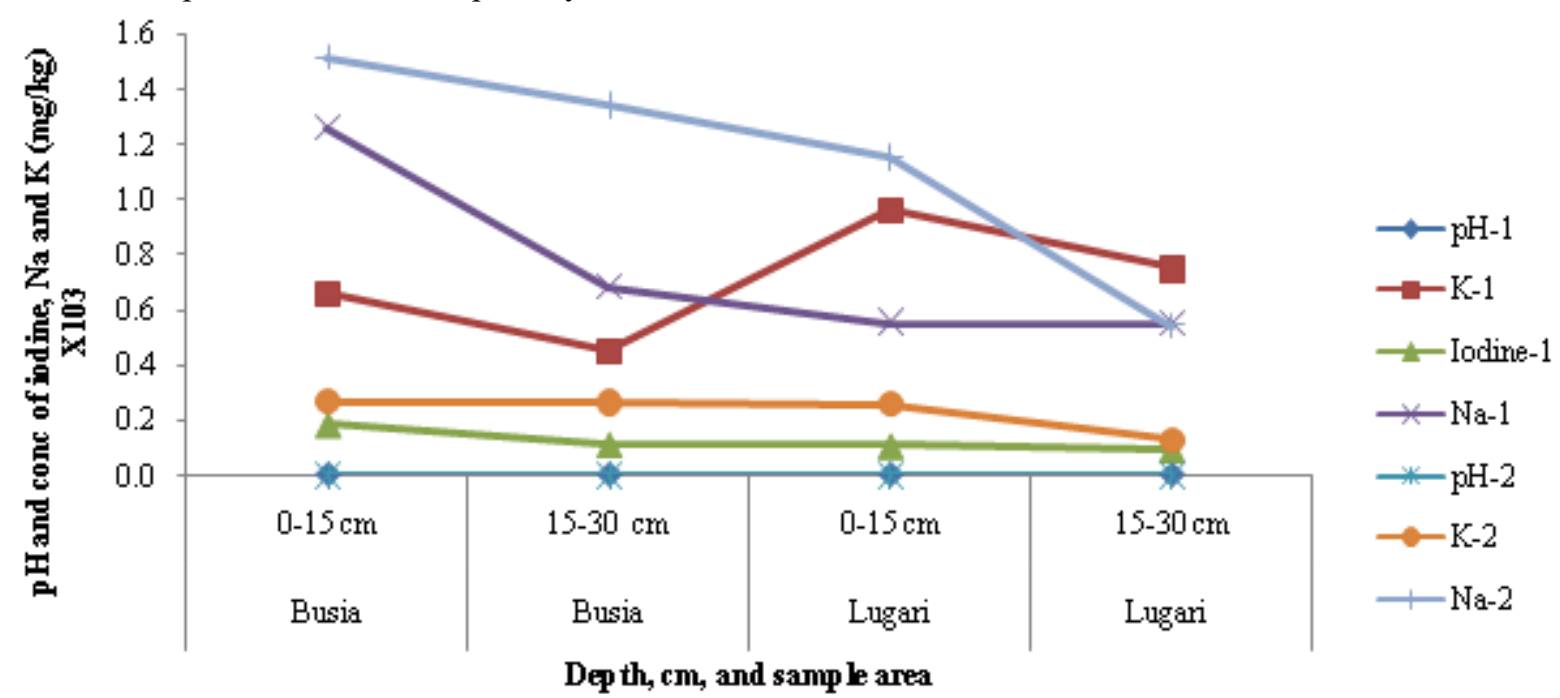

Volume 5 Issue 4, April 2016 


\section{International Journal of Science and Research (IJSR) \\ ISSN (Online): 2319-7064 \\ Index Copernicus Value (2013): 6.14 | Impact Factor (2015): 6.391}

Figure 2: Effect of depth $(\mathrm{cm})$ and seasonal changes on the Concentration of Iodine, $\mathrm{Na}$ and $\mathrm{K}$ in soil; for $1=$ wet season, $2=$ dry season

1.7.4 Concentration of Iodine, $\mathrm{Na}, \mathrm{K}$ and $\mathrm{Fe}^{2+}$ in Plants

There was higher concentration of iodine in Cyperus $P$. reeds from Bidimbidi than in Ululo for both the wet and dry seasons. In Lugari region, Matete division which is in the lower zone of River Nzoia had the highest iodine content than Lugari division which is in the upper zone of River Nzoia in both seasons (Figure 8). Both the two regions have higher humus content as can be explained by the increase in LOI hence higher organic matter content, which is a great reservoir for iodine. However, there is generally more uptake of iodine by Cyperus papyrus reeds than by Typha Latifolia, 0.164 versus 0.138 which agrees with findings by Zhu et al., (2004) and Wang et al., (2008). Although this is true from the results, iodine translocation from the soil to the reed plants is generally low due to leaching and sorption to soil surfaces. On the basis of the low uptake as evidenced from the low transfer factors since much is lost in gaseous form through sublimation as well as present as well as previous studies (Smolen and Sady 2011a, Smolen et al., 2011a, 2011b, 2011c) it can be stated that iodine influence on the uptake of mineral nutrients, heavy metals and trace elements by plants depend on numerous factors, including iodine concentration and soil depth but also is affected by variation of plants species in the preference (capacity) towards particular speciation of elements taken from soil. However, Busia reeds have more $\mathrm{Na}$ and $\mathrm{K}$ than Lugari reeds for both the wet $(2871.8 \mathrm{mg} / \mathrm{kg}>2519 \mathrm{mg} / \mathrm{kg})$ and the dry $(367 \mathrm{mg} / \mathrm{kg}>223 \mathrm{mg} / \mathrm{kg}$ ) seasons (Figure 6). Iodide may directly interact with clays by forming ion-pairs with like KI which may concentrate within the interlayer space as well as the thin areas surrounding the clay particle. Since the iodine levels in Busia are higher than Lugari it is expected that these elements may be high as well. Findings also revealed an inverse relationship between Iodine and $\mathrm{Cr}$ with $\mathrm{p}_{\text {value }}=0.0024$, coeff of -0.0036 , (

Appendix 8).The decrease in chromium due to oxidative reactions from $\mathrm{Cr}$ (VI) to $\mathrm{Cr}$ (III) may cause increased plantiodine content. While $\mathrm{Na}$ was highest in Busia samples than in the Lugari reeds, $(2871.8 \mathrm{mg} / \mathrm{kg}$ and $2519 \mathrm{mg} / \mathrm{kg}$, and $6351.1 \mathrm{mg} / \mathrm{kg}$ and $1596.9 \mathrm{mg} / \mathrm{kg}$ ) respectively both during the wet and the dry seasons, the amounts differs with finding by Ghani's (Ghani et al., 2012), who reported maximum concentrations $(\mathrm{mg} / \mathrm{L})$ of macro elements $\mathrm{Na}, \mathrm{K}$ as $728 \pm$ 0.60 and $28300 \pm 113$, respectively in herbal plants. Due to dissolution, there is more loss of $\mathrm{K}$ and $\mathrm{Na}$ from soil into the soil solution; however, it's notable that the concentrations of $\mathrm{K}$ and $\mathrm{Na}$ are higher in soils than in plants. The ranking order for $\mathrm{TF}$ for $\mathrm{Na}, \mathrm{Mg}, \mathrm{K}$ and iodine in studied reed samples was $\mathrm{Na}>\mathrm{K}>\mathrm{Mg}>\mathrm{I}$ for both Busia and Lugari regions (Table 6).

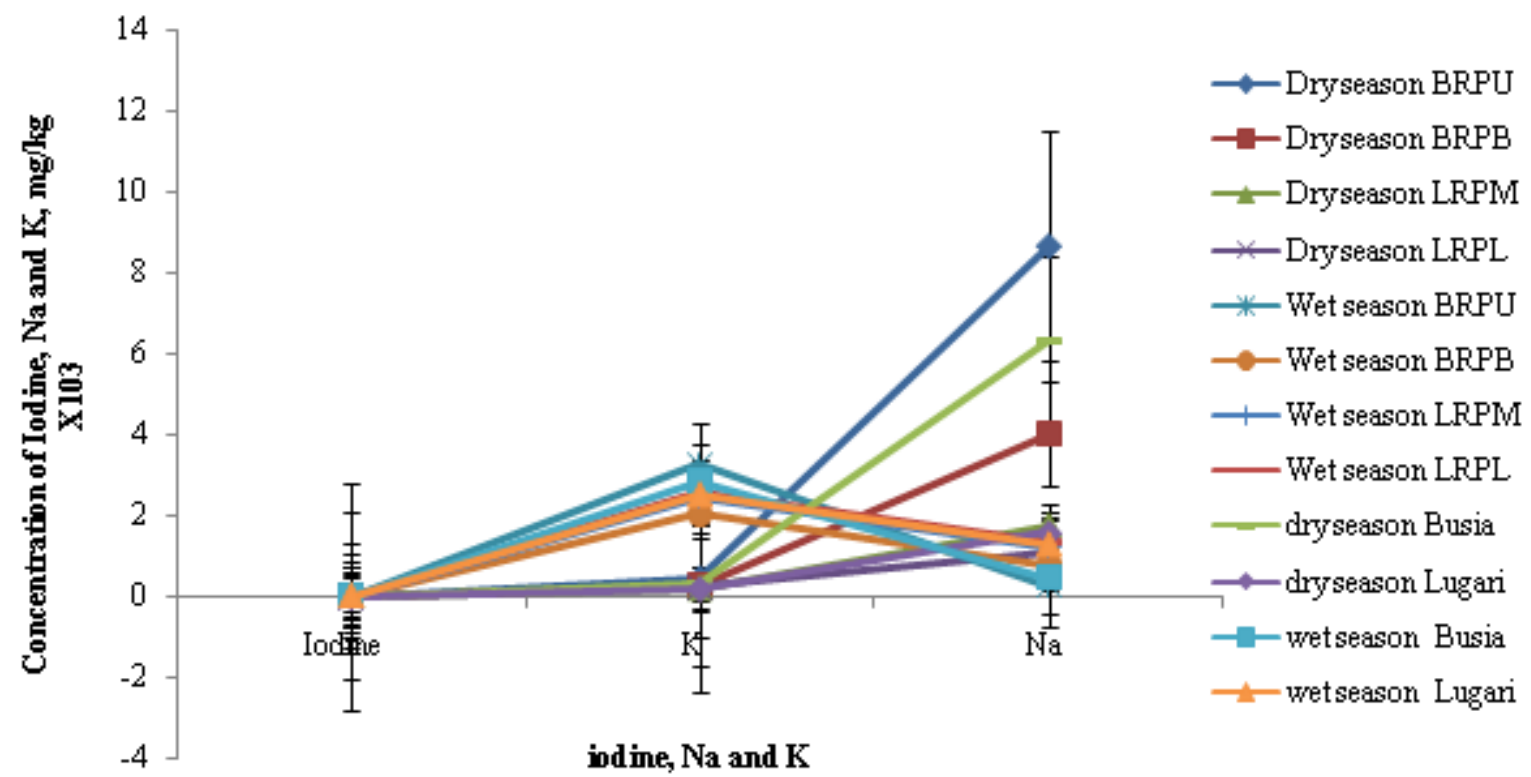

Figure 3: Average concentration of iodine, $\mathrm{K}$ and $\mathrm{Na}, \mathrm{mg} / \mathrm{kg}$, in plants per element per sampling area

\subsubsection{Concentration of Iodine, $\mathrm{Na}, \mathrm{K}$ and $\mathrm{Fe}^{2+}$ in Salt}

Salt samples analyzed for sodium, potassium and magnesium showed that $\mathrm{Na}$ has the highest concentration in salt samples from Busia but generally lower in Lugari compared to potassium, Figure 4. On average, Busia Cyperus papyrus salt has higher $\mathrm{Na}, \mathrm{pH}$ and moisture content but lower $\mathrm{K}, 11,930 \mathrm{mg} / \mathrm{kg}, 10.3,10.1 \%$ and $3,736.2 \mathrm{mg} / \mathrm{kg}$ compared to Lugari Typha latifolia salt whose $\mathrm{Na}, \mathrm{K}, \mathrm{pH}$ and moisture are $3,943.8 \mathrm{mg} / \mathrm{kg}, 4,635.8$ $\mathrm{mg} / \mathrm{kg}, 9.7$ and $0.8 \%$ respectively. From the correlation
Table, the amount of $\mathrm{Na}$ will decrease when that of $\mathrm{K}$ increases $(r=-0.7014)$ while salt $K$ will increase as that of soil $\mathrm{K}$ increases $(\mathrm{r}=0.7418$, Figure 4$)$. However, $\mathrm{Mg}$ is highest in Busia than in Lugari samples, showing a general trend of $\mathrm{Na}$ and $\mathrm{Mg}$ levels being inversely proportional to $\mathrm{K}$ concentrations. Matete and Lugari have lower $\mathrm{Na}$ and $\mathrm{K}$ levels compared to Ululo and Bidimbidi salts (Figure 4). As reported earlier there is high $\mathrm{K}$ and $\mathrm{Na}$ contents in Busia than in Lugari plant reeds hence higher $\mathrm{Na}$ and $\mathrm{K}$ is 


\section{International Journal of Science and Research (IJSR) \\ ISSN (Online): 2319-7064 \\ Index Copernicus Value (2013): 6.14 | Impact Factor (2015): 6.391}

expected to be translocated to the salt. This is expected since Busia plants have higher $\mathrm{Na}$ and $\mathrm{K}$ due to a higher translocation of the same from the soil to the plants as compared to Lugari, as indicated from their TF value where $\mathrm{K}$ and $\mathrm{Na} \mathrm{TF}$ values vary from Ululo $>$ Bidimbidi $>$ Lugari $>$ Matete ( while that of $\mathrm{Na}$ increases as the amount of $\mathrm{Fe}$ increases $\left(p_{\text {value }}=0.0475\right.$, coeff $\left.=180.5\right)$. On the other hand an increase in $\mathrm{Cd}$ level in the salt causes a decrease in $\mathrm{Na}$ content of the salt $\left(\mathrm{p}_{\text {value }}=0.0403\right.$, coeff $\left.=-139.6\right),($

Appendix 6).

Appendix 1). The amount of $\mathrm{K}$ in the salt is found to increase with increase in $\mathrm{Mg}\left(\mathrm{p}_{\text {value }}=0.0475\right.$, coeff $\left.=74.4\right)$,

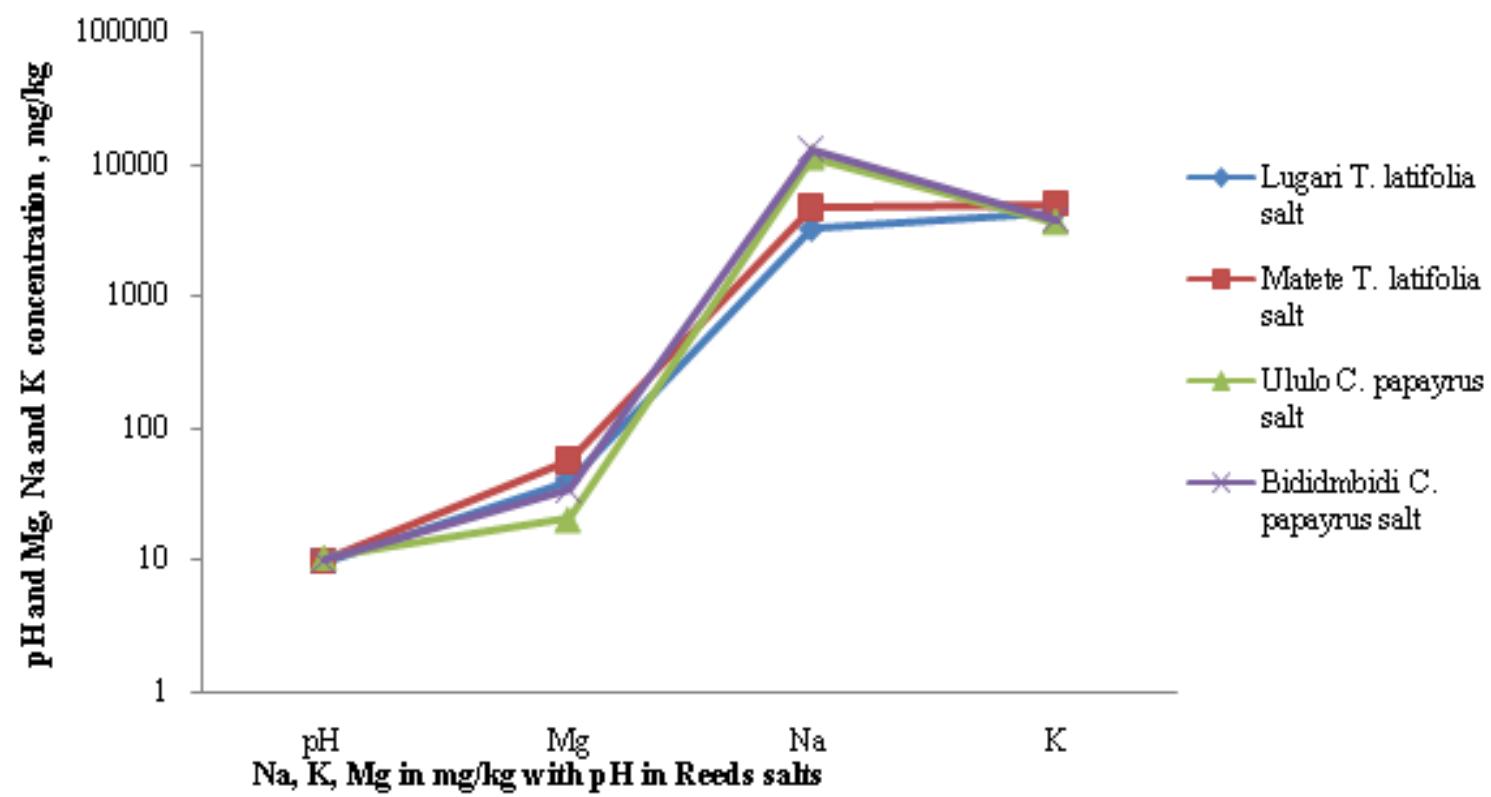

Figure 4: Comparison of the conc. of $\mathrm{Na}, \mathrm{K}, \mathrm{Mg}$ in $\mathrm{mg} / \mathrm{kg}$ with $\mathrm{pH}$ in Reeds salts

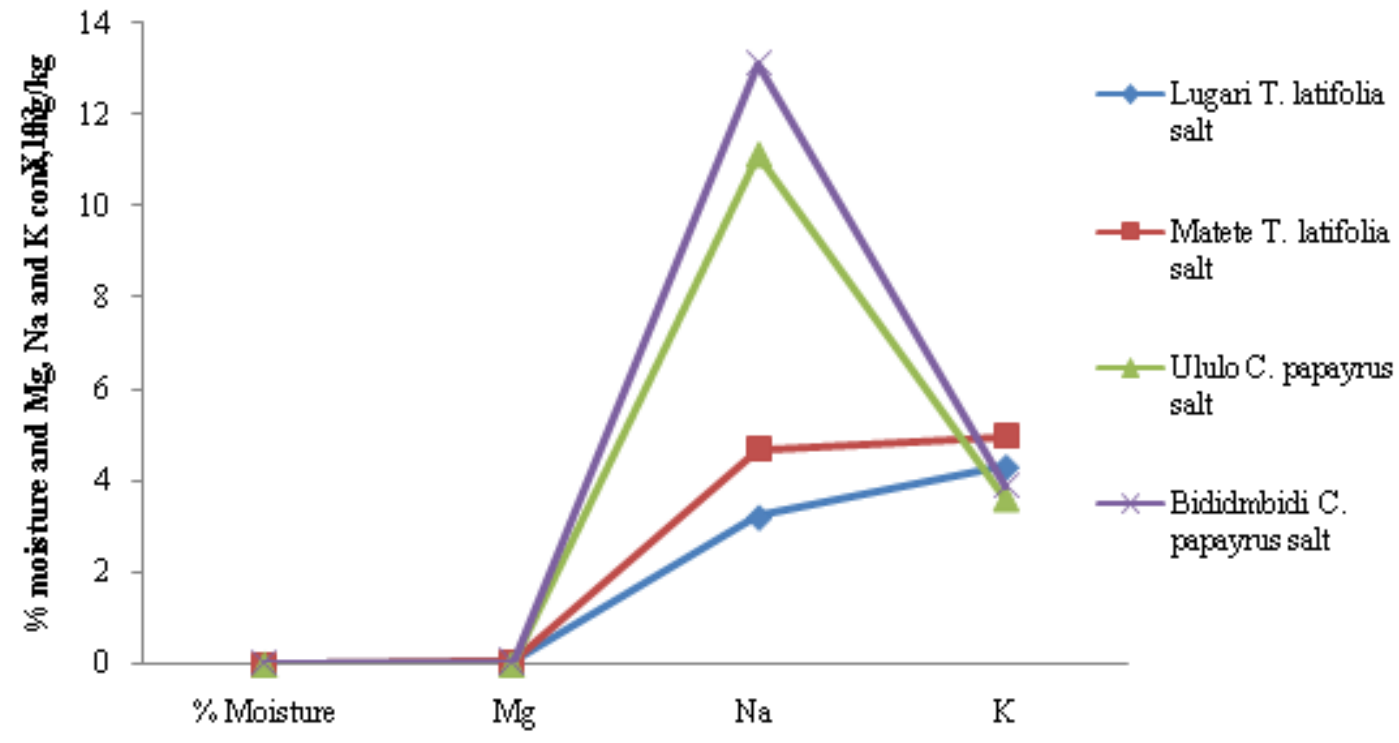

$\mathrm{Na}, \mathrm{K}$, Mg conc. (mg/kg) against $\%$ moisture in Reeds salts

Figure 5: Effect of moisture on the concentration of $\mathrm{Na}, \mathrm{K}, \mathrm{Mg}(\mathrm{mg} / \mathrm{kg})$ in reed salts

On the other hand, the $\mathrm{Mg}$ content was higher in Lugari Typha latifolia salt than in Busia Cyperus papyrus salt with Matete $>$ Lugari $>$ Ululo $>$ Bidimbidi. It can be concluded that the higher the $\mathrm{Na}, \mathrm{pH}$ and \% moisture the lower the $\mathrm{Mg}$ content and vice versa in reed salts. Equally, Typha latifolia reed salt tend to have higher levels of $\mathrm{Mg}$ and $\mathrm{K}$ than $\mathrm{Na}$ which the reverse is true for Cyperus papyrus that tends to contain higher $\mathrm{Na}$ and lower $\mathrm{K}$ and $\mathrm{Mg}$. secondly, Typha latifolia salts have a lower $\mathrm{pH}$ and moisture content compared to Cyperus papyrus salt. The method used for preparing Typha latifolia salt expenses more moisture than that used in Busia on Cyperus papyrus salt. Comparing the $\mathrm{Na}$ : K ratio of the types of reed salts, T. latifolia has $0.85: 1$ while $C$. papyrus has $3.2: 1$ compared to $4: 1$ recommended by WHO 2006. For an ideal food grade salt, Cyperus papyrus salt may be better than Typha latifolia which is far from the required Na: K ratio, Figure 7. However, Typha latifolia salt may be recommended for a Lo-Na salt since its 


\section{International Journal of Science and Research (IJSR) \\ ISSN (Online): 2319-7064 \\ Index Copernicus Value (2013): 6.14 | Impact Factor (2015): 6.391}

$\mathrm{Na}: \mathrm{K}$. The trend from the highest to the lowest was $\mathrm{Na}>\mathrm{K}$ $>\mathrm{Mg}$ for Busia while for Lugari it was $\mathrm{K}>\mathrm{Na}>\mathrm{Mg}$, although the difference between $\mathrm{Na}$ and $\mathrm{K}$ in Lugari salts was very minimal. Comparing the salt samples' $\mathrm{Na} / \mathrm{K}$ ratio with the recommended ratio of $2.5: 1$ and $4: 1$, it can be observed that Lugari samples are well below the 2.5:1 to 4:1 ratio (mean of $\mathrm{Na}$ : $\mathrm{K}$ of 0.9 ) while for Busia salts processed from C. papyrus is slightly below the recommended limit of 2.5-4 for Na: 1 for $\mathrm{K}$, with a mean $\mathrm{Na}: \mathrm{K}$ ratio of 3.2 (Figure 7). This suggests that indigenous reed salt from Busia's $C$. papyrus reeds is the more ideal salt for an acceptable $\mathrm{Na}$ : $\mathrm{K}$

Table 5 are presented in table belo

Iodine and $\mathrm{Fe}^{2+}$ were compared and the reed salts have lower iodine contents as compared to commercial salts while their $\mathrm{Fe}^{2+}$ is comparable to the commercial salts. The iodine concentration is of the order Kensalt $>$ Top-chef salt $>$ Herbal sea salt $>$ Sea salt $>$ Typha latifolia salt $>$ Cyperus papyrus saltwhile for $\mathrm{Fe}^{2+}$ is of the order Herbal sea salt $>$ Typha latifolia salt $=$ Cyperus papyrus salt $>$ Sea salt $>$ Kensalt $=$ Top-chef salt.

Typha L. and Cyperus P. salts $\mathrm{Na}, \mathrm{K}$, and $\mathrm{Mg}$ levels compares well with commercial salts. It is apparent from the results that the sodium levels increased with increase in $\mathrm{pH}$ and $\%$ moisture of the salt. For instance, Lugari had $\mathrm{pH}$ range of 9.56 to 9.76 while Busia's $\mathrm{pH}$ range was 10.23 10.55 respectively. From the results in Figure 6, the three

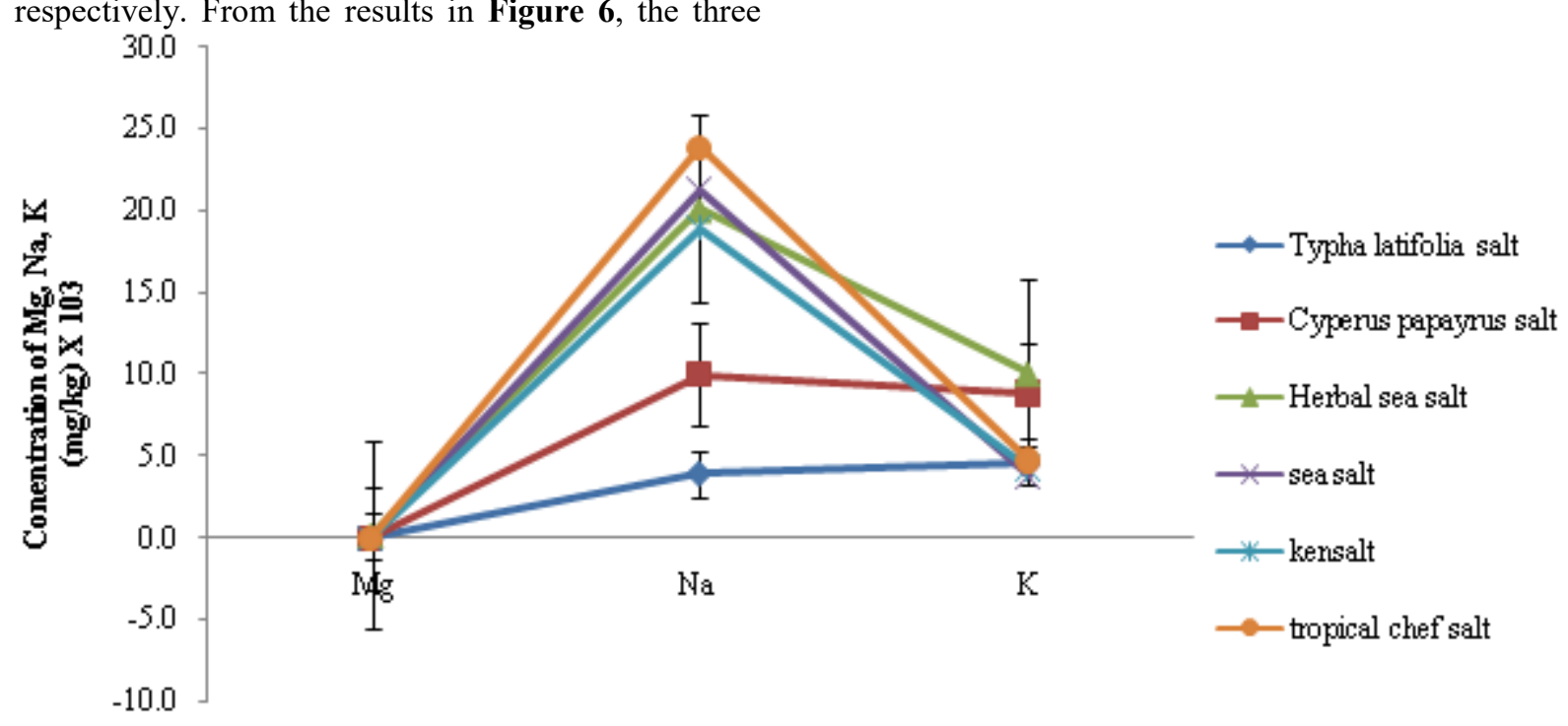

Types of reed salt as compared to commercials salts

Figure 6: A comparison of the mean concentration of $\mathrm{Na}, \mathrm{K}$ and $\mathrm{Mg}$ in Reed species salts with salts from the market. (HSSA - Herbal salt; TCSA - Top-chef table salt; KNSA - Kensalt; SSSA - Sea salt naturals)

The level of iron (II) is higher than iodine comparatively in all the salts from the two reed species of the two sampled regions respectively. Iodine and $\mathrm{Fe}^{2+}$ levels in Cyperus papyrus salts from Busia region increased from the dry season to the wet season, from 0.6 to $1.2 \mathrm{mg} / \mathrm{kg}$ and 0.9 to $1.0 \mathrm{mg} / \mathrm{kg}$ respectively (Figure 8 and Figure 9). On the other hand the iodine content for Typha latifolia decreased from 1.3 to $0.9 \mathrm{mg} / \mathrm{kg}$ from dry to wet season while that of $\mathrm{Fe}^{2+}$ increased from 1.1 to $1.4 \mathrm{mg} / \mathrm{kg}$ in the same seasons. However, both Iodine and Iron were higher in T. latifolia reeds than $C$. papyrus. since the $\mathrm{K}$ content of $T$. latifolia was higher than that of $C$. papyrus, it is expected that iodine ratio as table or common salt, while Lugari's Typha latifolia salt could be used as a Lo-Na salt.

Cyperus papyrus is a better bioaccumulator for $\mathrm{Na}$ than $\mathrm{K}$ and $\mathrm{Mg}$ while Typha latifolia is better accumulating $\mathrm{Mg}$ and $\mathrm{K}$ than $\mathrm{Na}$, as is evident from

Appendix 6. The chemical composition of the two salts was also compared with that in edible salts obtained from the supermarkets in Western Kenya and the results are presented in $\mathrm{W}$

elements in all salts were of the order $\mathrm{Na}>\mathrm{K}>\mathrm{Mg}$, with $\mathrm{Na}$ being highest in TCSA, 23,855 mg/ $\mathrm{kg}, \mathrm{K}$ and $\mathrm{Mg}$ highest in HSSA, $8813.5 \mathrm{mg} / \mathrm{kg}$ and $156.5 \mathrm{mg} / \mathrm{kg}$ respectively. The $\mathrm{Na}$ : $\mathrm{K}$ ratio of the salts is such that they fall between $0.9: 1$ to 5.0:1 (Figure 7). Currently dietary guidelines in the US recommend limiting salt intake to 1.5-2.4 grams of sodium per day while the American Heart Association suggests 1.5 gram limit. For a frame reference, one tea spoon of regular table salt contains about 2.3 grams of sodium. Data from around the world suggest that the population average sodium consumption is well above the minimal physiological needs, and in many countries is above the value recommended by the 2002 Joint World Health Organization/Food and Agriculture Organization of the United Nations (WHO/FAO) Expert Consultation (WHO, 2013) of $2 \mathrm{~g}$ sodium/day (equivalent to $5 \mathrm{~g}$ salt/day) (WHO, 2013). should vary proportionally as supported by the correlation of $\mathrm{K}$ to Iodine $(\mathrm{r}=0.5466)$, due to their chemical interaction while forming KI compounds. There is a general trend for iodine and $\mathrm{Fe}^{2+}$ in these reeds such that while there is an increase in iodine there is a decrease in $\mathrm{Fe}^{2+}$. The amount of iodine increased with increase in $\mathrm{K}$ levels, due to the chemical interaction with $\mathrm{K}$ than $\mathrm{Na}$. Salt iodine was observed to positively relate with the plant iodine as well as soil iodine $(\mathrm{r}=0.5247$ and 0.6449 ;

\section{Appendix 4).}




\section{International Journal of Science and Research (IJSR) \\ ISSN (Online): 2319-7064}

Index Copernicus Value (2013): 6.14 | Impact Factor (2015): 6.391

The mean salt iodine concentrations for Lugari's Typha latifolia salts was $1.1 \pm 0.18 \mathrm{mg} / \mathrm{kg}$ and $0.9 \pm 0.31 \mathrm{mg} / \mathrm{kg}$ for Busia's Cyperus papyrus salts respectively, lower than the worldwide average of $5 \mathrm{mg} \mathrm{kg}^{-1}$ (Fleming, 1980; Ure and Berrow, 1982) and the UK average of $9.2 \mathrm{mg} \mathrm{kg}^{-1}$ (Whitehead, 1979). There is need to increase the iodine levels in the salts from the two regions of Western Kenya.

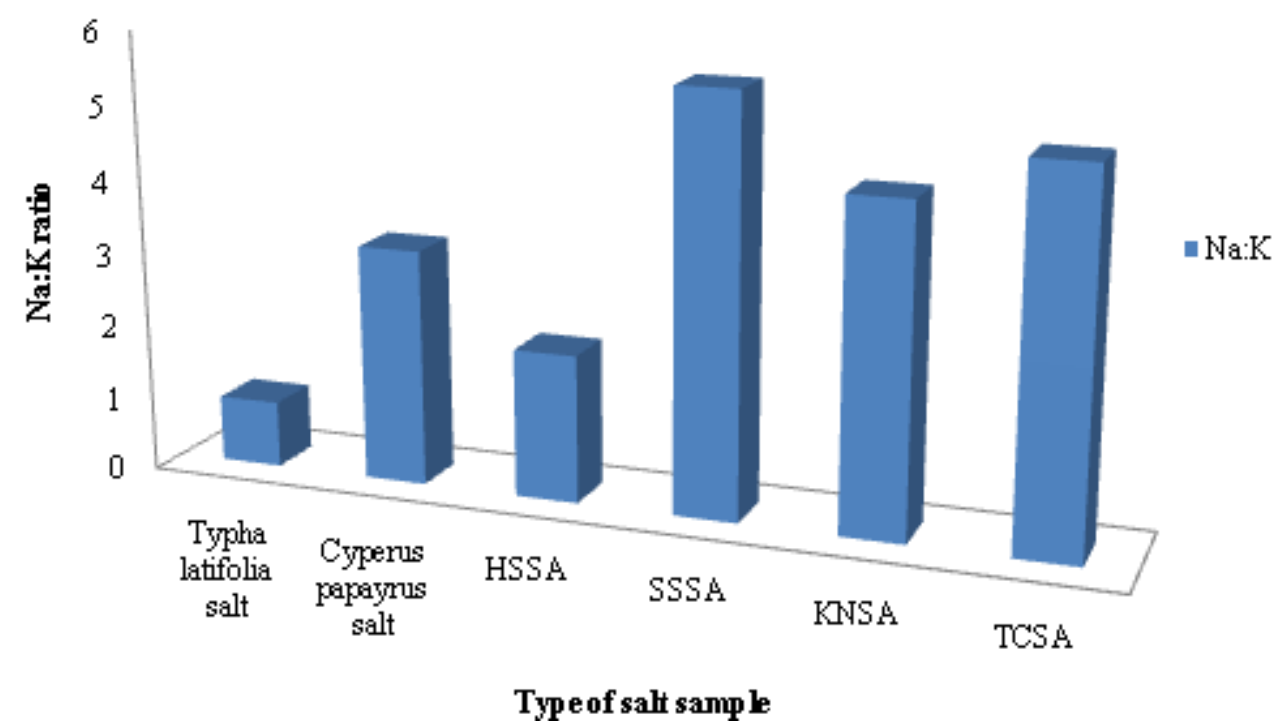

Figure 7: Na: K ratio for Typha latifolia and Cyperus papyrus and the commercial salts

Iodine concentration varied inversely with $\mathrm{pH}$ of the salt. The $\mathrm{pH}$ of the salt has insignificant effect on the iodine concentration of the salt. $\mathrm{Fe}^{2+}$ levels seemed to generally decrease with increase in $\mathrm{pH}$ while there was no significant relationship with $\%$ moisture. Results indicate a similar trend in the concentrations of $\mathrm{Fe}^{2+}$ in Lugari and Busia counties with a mean of $1.1 \pm 0.001 \mathrm{mg} / \mathrm{kg}$ and $1.0 \pm 0.001$ $\mathrm{mg} / \mathrm{kg}$ respectively.

It is clear that $T$. latifolia salts accumulates more iodine than $C$. papyrus during the dry season than in the wet season probably due to increased oxidation, while the same is true for $\mathrm{Fe}^{2+}$, the variation is minimal (Figure 8). The amount of $\mathrm{Fe}^{2+}$ seems to increase with a decrease in $\%$ moisture content of the salt. Moisture is naturally present in the salt, or is abstracted from the air by hygroscopic impurities such as magnesium chloride. The presence of moisture and some hygroscopic impurities and metal ions impurities such as iron accelerates the loss of iodine (Diosady et al., 1998). As is the case for moisture content, it is clear that the salts from Busia recorded on average the lowest iodate contents, which is true with the moisture contents that were high. It is therefore important to prepare this salt to ensure lower moisture levels so as to have higher iodate contents.

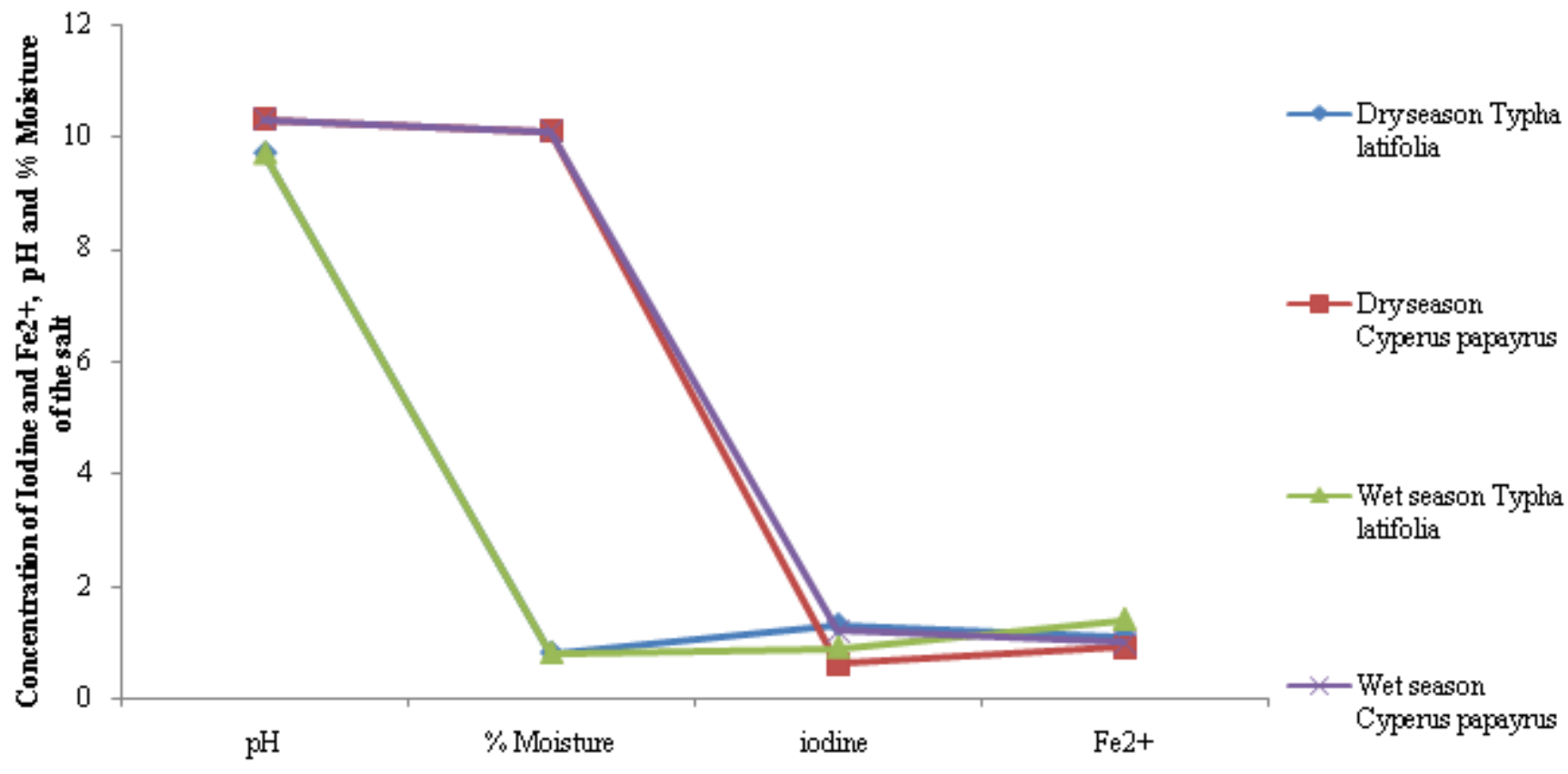

$\mathrm{pH}$ and Moisture with indine and $\mathrm{Fe} 2+$ concnetration, $\mathrm{mg} / \mathrm{kg}$

Figure 8: Concentration of Iodine and $\mathrm{Fe}^{2+}, \mathrm{mg} / \mathrm{kg}$ in salt samples from various sites 


\section{International Journal of Science and Research (IJSR) \\ ISSN (Online): 2319-7064}

Index Copernicus Value (2013): 6.14 | Impact Factor (2015): 6.391

Typha latifolia salt is highly related to $\mathrm{pH}$ and \% moisture content of the salt. Higher $\mathrm{pH}$, lower $\%$ moisture, higher Iodine and increased Iron concentration, Figure 9. Salt samples from Lugari County had the highest iodate concentration with a mean of $1.0 \pm 0.001 \mathrm{mg} / \mathrm{kg}$ of the salt, with the highest from Lugari division and the lowest from Matete division, while Busia had a mean of $1.1 \pm 0.001$ $\mathrm{mg} / \mathrm{kg}$ of the salt. Iodine availability in the absence of dietary seafood sources depends largely on its transfer from soil to food and fodder crops (Johnson et al., 2002). Transfer of iodine from soil to plants is generally low and locally grown plants often cannot supply a population with the recommended daily intake of iodine (Johnson, 2003). There is therefore a need to increase understanding of iodine behaviour in soils of Lugari and Busia if the resulting implications for transfer to crops and livestock are to be understood. Although some of the plant salts contain iodate the amount is very low compared to the recommended levels and there is need for iodization of the salt as well.

\subsubsection{Concentration of Iodine and Iron (II) in reed salts and commercial salts}

The concentration of Iodine was highest in KNSA $>$ TCSA $>$ HSSA $>$ SSSA than in the reed salts that recorded $<2.0$ $\mathrm{mg} / \mathrm{kg}$ dry weight as evident from Figure 9. Iodine is low in the reed salts than in the commercially available salts. $\mathrm{Fe}^{2+}$ is higher in the reed salts than in the commercially available salts, with Typha latifolia having the highest iodine of 43.64 $\mathrm{mg} / \mathrm{kg}$ as compared to Cyperus papyrus with $34.75 \mathrm{mg} / \mathrm{kg}$. There is need to moderate the amounts of iodine and $\mathrm{Fe}^{2+}$ in the reed salts probably through salt fortification since these elements are essential in combating goiter and anemia respectively.

The recommended Dietary Allowances (RDA) for iodine and iron are $0.015 \mathrm{mg} / \mathrm{kg}$ and $8 \mathrm{mg} / \mathrm{kg}$ respectively, with an Upper Limit (UL) of $1.1 \mathrm{mg} / \mathrm{kg}$ and $45 \mathrm{mg} / \mathrm{kg}$ respectively. It therefore shows that Typha latifolia and Cyperus papyrus reed salts have slightly higher iodine $(2.0 \mathrm{mg} / \mathrm{kg})$ than required while that of iron is within the recommended limit. The amount of $\mathrm{Mg}$ in the reed salts is comparable to that of the other commercial salts, with Typha latifolia and Cyperus papyrus reed salts having $21.3 \mathrm{mg} / \mathrm{kg}$ and $12.6 \mathrm{mg} / \mathrm{kg}$ respectively compared to a range of $15.4-156.5 \mathrm{mg} / \mathrm{kg}$ for the selected commercial salts. 


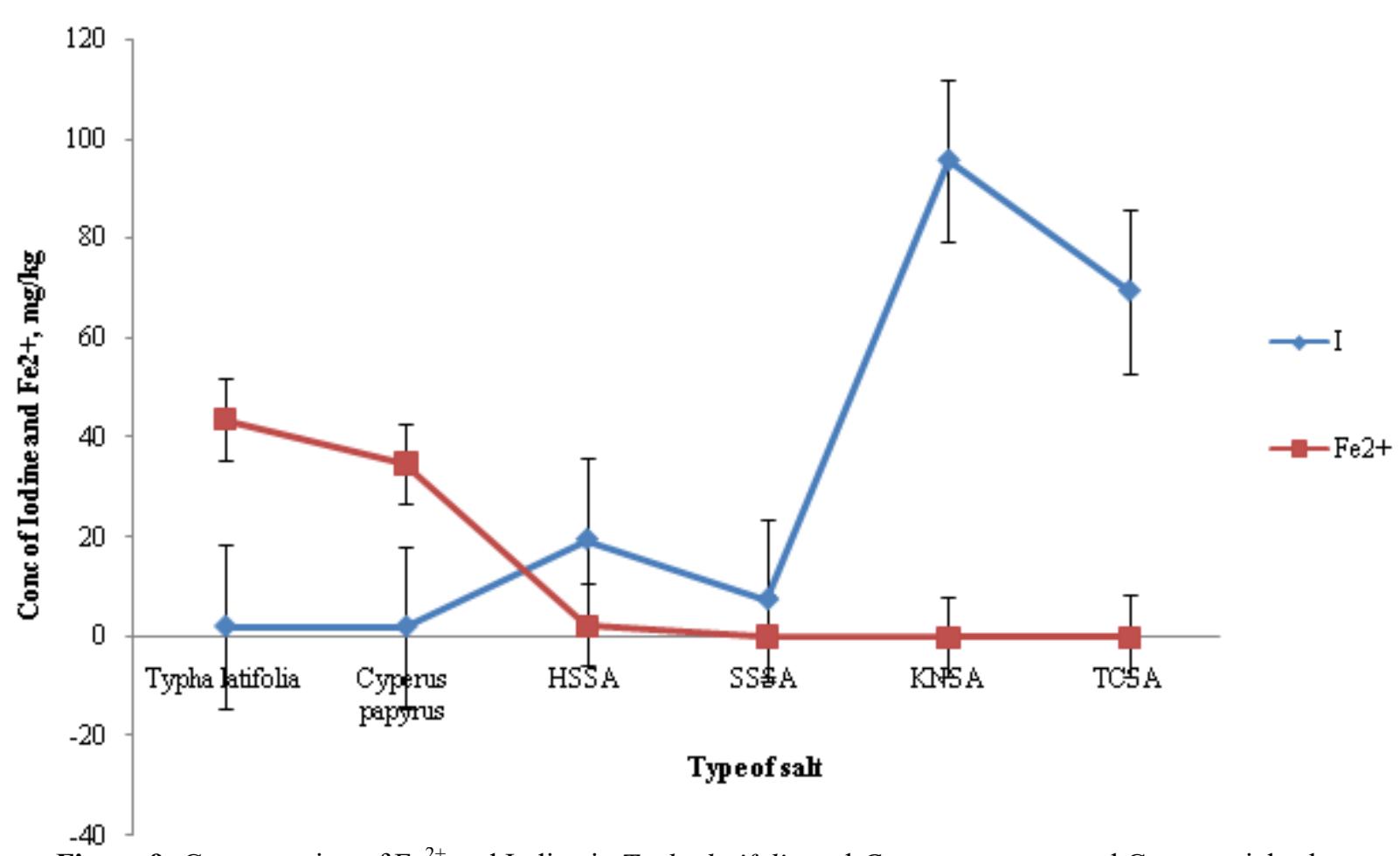

Figure 9: Concentration of $\mathrm{Fe}^{2+}$ and Iodine in Typha latifolia and Cyperus papyrus and Commercial salts 


\section{International Journal of Science and Research (IJSR) \\ ISSN (Online): 2319-7064 \\ Index Copernicus Value (2013): 6.14 | Impact Factor (2015): 6.391}

\subsection{Risk Assessment}

Risk assessment, as a part of risk analysis, a process of evaluating the possibility of adverse health effects that may occur as a consequence of exposure to a hazard, was evaluated. The health risk of the toxicity associated with the indigenous reeds salt was done by estimating the level of exposure of the heavy metals through the food chain. The

Table 7).

\subsubsection{Estimation of the dietary intake of the studied heavy metals (EDIM)}

The dietary intake of the studied heavy metals was estimated and their associated risks were studied by comparing to the provisional tolerable weekly intakes (PTWIs). Considering the average daily salt intake to be $5 \mathrm{~g} /$ day, PTWI was calculated using the formula provided by Pourgheysari 2012; Lee et al. , 2006:

Estimated Daily Intake of Metal (EDIM)

The Estimated daily oral intake of metals (EDIM) from soil through the consumption of reed salt in $\mathrm{mg}$ was calculated as in equations 9-12 below:

Daily intake of heavy metals

$=$ (concentration of heavy metals in the salts)

* (mean salt intake $)(\mathrm{g} /$ person $) /$ day $) 9$

Table 7). The commercial salts have $\mathrm{K}$ range between $36-87$ with Herbal sea salt having the highest, whereas T. latifolia has 311 and 230 for C. papyrus. On the other hand $\mathrm{Na}$ levels in T. latifolia and C. papyrus are 311 and 1032 respectively while commercial salts range from 1576-1988, which are higher than the reed salts. There is high $\mathrm{K}$ and lower $\mathrm{Na}$ levels in the reed salts as compared to the Kenya Bureau of statistics certified commercial salts analysed which are in the market. However, from the results of EDIM the

Table 7). The Adequate Intake (AI) for sodium is 1,500 milligrams daily for males and females ages 9-50 (Nguyen et al., 2013). This value is less than 1 teaspoon of table salt per day. The maximum recommended level of sodium intake is 2,300 milligrams daily (U.S. Department of Agriculture and U.S. Department of Health and Human Services, 2010). The daily intake for both Busia and Lugari people is higher than the maximum recommended level of sodium intake of 2,300 milligrams daily.

\subsubsection{Estimated Health Risk Index (EHRI)}

To assess the health risk of persons using these reeds salt in the study area, the daily intake rates of metal (DIM) and the health risk index were estimated. Estimated health risk index (EHRI) is the ratio of estimated daily intake of metal (EDIM) to the reference dose (RD) is which is the maximum tolerable daily intake of a specific metal that does not result degree of toxicity of heavy metal to human depends on the daily intake. Typha latifolia and Cyperus papyrus reed salts were selected and their health risk assessment calculated in terms of estimated daily intake of metal (EDIM) and estimated health risk index (EHRI) by considering the intake of metal through the salts by the consumers (

Appendix

and

Weekly intake of heavy metals, (PTWIs)

$=$ daily intake $x$ seven days

/ week 10

Weekly intake per bodyweight $\mathrm{kg}$,

$$
\begin{gathered}
=\frac{\text { PTWIs weekly intake }}{\text { reference bodyweight } 60 \mathrm{~kg}} 11 \\
E D I=\text { CHM } x \frac{\text { WCASS }}{B W} 12
\end{gathered}
$$

Where CHM (mg/kg, on fresh weight basis) is the concentration of heavy metals in salt; WCASS represents the daily average consumption of salt by consumers in the study areas; and BW is the adult's body weight. The WCASS for this study was taken as $5 \mathrm{~g} /$ day. An adult's average body weight of $60 \mathrm{~kg}$ was used for the EDI evaluation.

Comparing the calculated daily intake in relation to the commercial salts, both $T$. latifolia and $C$. papyrus salts have higher EDIM values for $\mathrm{Na}$ and $\mathrm{K}$ ( consumption of reed salt processed from Cyperus papyrus is better than for Typha Latifolia as the dietary intake of $\mathrm{Cr}$ and $\mathrm{Fe}$ in adults is lower than the permissible limits (WHO, 1996), while its $\mathrm{Pb}$ and Cd EDIM values are higher than for Cyperus papyrus reed salt. The daily intake of heavy metals was estimated on the basis of the average consumption and concentration of metal in Typha latifolia and Cyperus papyrus reed salts. Based on the above concentrations, the estimated daily intake of metal (EDIM) for adults through food chain was calculated

in any harmful health effects. The HRI has been recognized as a very useful index to evaluate the health risk associated with the consumption of heavy metal contaminated food and food additives (USEPA, 2002; Cui et al., 2004 and Wang et al., 2005). The oral reference dose (RD) for $\mathrm{Cd}, \mathrm{Pb}$ and $\mathrm{Cr}$ are $1.0 \mathrm{E}-03,3.5 \mathrm{E}-03$ and $1.5 \mathrm{E}-00 \mathrm{mg} \mathrm{kg}^{-1} \mathrm{day}^{-1}$, respectively given by US-EPA (2002), IRIS (2003). If the value of EHRI is less than one then the exposed population is said to be safe and if greater than one indicating that there is a potential risk associated with that metal (IRIS, 2003). From the estimated Health Risk index (EHRI) 


\section{International Journal of Science and Research (IJSR)

Table 7) values obtained it is evident that the exposed population is not safe since the $\mathrm{Cd}$ and $\mathrm{Pb}$ EHRI values for both salt samples are greater than one indicating that there is a potential risk associated with $\mathrm{Cd}$ and $\mathrm{Pb}$ metals. The higher the EHRI value, the higher the probability of experiencing long term carcinogenic effects (USEPA, 2002). The order of dominance of HRI index for the metal is $\mathrm{Pb}>$ $\mathrm{Cd}$. This clearly shows that the local inhabitants are most likely to be exposed to potential health risk from dietary $\mathrm{Pb}$ and $\mathrm{Cd}$.

\subsubsection{Soil-Plant Partition Coefficient or Transfer Factor (TF)}

To characterize quantitatively the transfer of an element from soil to plant, the soil-plant Partition Coefficient or Transfer Factor (TF) or Concentration Ratio or Biological Accumulation Coefficient (BAC) that expresses the ratio of contaminant concentration in plant parts to concentration in dry soil was determined (Table 6) using methods by Rodriguez et al., 2002; Tome et al., 2003. A prerequisite of the soil-plant transfer factor concept is the presence of a statistically significant relationship between the content of a given element in the soil and plant (Bunzl et al., 2000). Generally, from farming and other human activities, chemicals entering the water system, subsequently, enter the soil. The soil absorbs part of the chemicals which, subsequently, become part of the photosynthetic processes. It was therefore expected that the concentrations of metals in the reed plants would reflect the concentrations in the soil samples. On the basis of transfer factor values the higher the value of transfer factor, the more element would be accumulated by plants.

The correlation between metal contents measured in soils vis-a-vis reeds plants was found to be quite varied (

Appendix 4) $\mathrm{K}$ had the highest $\mathrm{TF}$ values (10472) in the wet season, while $\mathrm{Na}$ was the highest (69) in the dry season. Equally for micronutrients, a sequence of decreasing TF values: $\mathrm{Na}>\mathrm{K}>\mathrm{I}>\mathrm{Mg}$ can be generalized for plants in both regions for the dry season, and $\mathrm{Mg}>\mathrm{K}>\mathrm{Na}>\mathrm{I}$ for the wet season. It is necessary to take into consideration the fact that the content of metal in plant is influenced by a variety of factors, including: plant species, type of soil and its physicochemical properties. Also, metals are taken up by plants not only from soil, but also from air deposition and water. Additionally, soil $\mathrm{pH}$, soil texture and $\mathrm{BD}$ also have influence on the metal content in plants, since this determines the amount of the metals in the soils thereby affecting the amount translocated to the plant either by increase or decrease of the same.

\subsubsection{Ash-Salt Partition Coefficient or Transfer Factor (TF)}

The TF values for the dry season are higher than those obtained for the wet season which implies that more metals are present in the environment during the dry season than the wet season (Table 6). There is also dilution factor as a result of the rains runoff, reducing their concentrations.

\subsection{Conclusion and Recommendations}

\subsubsection{Conclusion}

Salts from selected reed plants (Typha latifolia and Cyperus papyrus) are used by the inhabitants of the Lugari and Busia counties of Western Kenya. Cyperus P. and Typha L. reeds of Lugari and Busia regions respectively, grow in weak acidic soils of $\mathrm{pH}$ range from 4.9-6.5. The concentration of soil-Na was found to be inversely related to $\mathrm{t}$ soil- $\mathrm{K}, \mathrm{Mg}$ and $\mathrm{Ca}$ concentrations and SBD, while the $\mathrm{Na}$ concentration increased with increase in CEC and \% clay in the soil. The concentration of $\mathrm{K}$ was found to be linearly related to $\mathrm{pH}, \%$ moisture, \% clay, iodine and $\mathrm{Mg}$ while it had a negative relation with \% N, CEC, \% sand, \% silt, SBD, \% LOI, P and iodine. The amount of soil nutrients as well as heavy metal content largely depends on soil depth as well as seasonal variation. An increase in depth led to a decrease in iodine level in soil with the top soils, $0-15 \mathrm{~cm}$, recording higher iodine content than sub-soils $15-30 \mathrm{~cm}$ deep. Equally, it was found that iodine increases with increase in SBD and \% clay. The results also show that the lower the moisture content the lower the iodine level. $\mathrm{Fe}^{2+}$ concentration increased with increase in depth in the dry season, with Ululo having the highest iron concentration while the least was Bidimbidi at $15-30 \mathrm{~cm}$ depth.

There was higher concentration of iodine in Cyperus papyrus reeds from Bidimbidi than in Ululo for both the wet and dry seasons. Matete division which is in the lower zone of River Nzoia in Lugari region had the highest iodine content than Lugari division which is in the upper zone of River Nzoia in both seasons. However, there is generally more uptake of iodine by Cyperus papyrus reeds than by Typha Latifolia. Findings also revealed an inverse relationship between Iodine and $\mathrm{Cr}$ where an increase in iodine contributed to a decrease in $\mathrm{Cr}$ and vice versa. However, iodine increased with an increase in $\mathrm{Cd}$ and $\mathrm{Fe}$ levels. The $\mathrm{K}$ content of $T$. latifolia was higher than that of C. papyrus with $\mathrm{K}$ levels increasing with increase in iodine concentration in plants. In the present study, Iodine, $\mathrm{K}, \mathrm{Na}$, concentrations increased with ashing process while a decrease in $\mathrm{Mg}$ was noted. The process of salt preparation from reeds therefore affects the salt product and hence ashing process is an important step in regard to indigenous reed salt production. From this study, it was noted that Typha latifolia reed ash accumulated less $\mathrm{K}$ as compared to Cyperus papyrus ash.

Salts obtained from Cyperus papyrus reed plants that thrive in swampy areas have higher moisture contents than those from Typha latifolia. The order of decreasing concentration of the micronutrients in the salt is of the form $\mathrm{Na}>\mathrm{K}>\mathrm{Mg}$ for Busia while for Lugari it was $\mathrm{K}>\mathrm{Na}>\mathrm{Mg}$, although the difference between $\mathrm{Na}$ and $\mathrm{K}$ in Lugari salts was very minimal. On average, Busia Cyperus papyrus salt has higher $\mathrm{Na}, \mathrm{pH}$ and moisture content but lower $\mathrm{K}$ compared to Lugari Typha latifolia salt whose $\mathrm{Na}, \mathrm{K}, \mathrm{pH}$ and moisture and the amount of $\mathrm{Na}$ will decrease when that of $\mathrm{K}$ increases. $\mathrm{Mg}$ content was higher in Lugari Typha latifolia salt than in Busia Cyperus papyrus salt with Matete $>$ Lugari $>$ Ululo $>$ Bidimbidi. Although $\mathrm{Na}$ and $\mathrm{Mg}$ levels were found to be negatively related to $\mathrm{K}$ concentrations in the reed salts, 


\section{International Journal of Science and Research (IJSR) \\ ISSN (Online): 2319-7064 \\ Index Copernicus Value (2013): 6.14 | Impact Factor (2015): 6.391}

Cyperus papyrus salt had higher levels of $\mathrm{Mg}$ and $\mathrm{K}$ than $\mathrm{Na}$ as compared to Typha latifolia reed salt. $\mathrm{Fe}^{2+}$ levels in the reed salts generally decreased with increase in $\mathrm{pH}$ while there was no significant relationship with $\%$ moisture.T. Latifolia salts prepared during the dry season contained more iodine than $C$. papyrus salt as compared to the one prepared in the wet season. Comparing the salt samples' $\mathrm{Na} / \mathrm{K}$ ratio with the recommended ratio of $2.5: 1$ and $4: 1$, it can be observed that Lugari Typha latifolia salt samples had a Na:K of 0.9 while Busia's C. papyrus salt had a Na:K ratio of 3.2. The iodine concentration for the analysed salts was of the order Kensalt $>$ Top-chef salt $>$ Herbal sea salt $>$ Sea salt $>$ Typha latifolia salt $>$ Cyperus papyrus saltwhile for $\mathrm{Fe}^{2+}$ is of the order Herbal sea salt $>$ Typha latifolia salt = Cyperus papyrus salt $>$ Sea salt $>$ Kensalt $=$ Top-chef salt. Typha latifolia and Cyperus papyrus reed salts have slightly higher iodine $(2.0 \mathrm{mg} / \mathrm{kg})$ than the recommended Dietary Allowances (RDA) for iodine $(0.015 \mathrm{mg} / \mathrm{kg})$ while that of iron is within the recommended limit $(8 \mathrm{mg} / \mathrm{kg})$, with an Upper Limit (UL) of $1.1 \mathrm{mg} / \mathrm{kg}$ and $45 \mathrm{mg} / \mathrm{kg}$ respectively.

The concentrations of $\mathrm{K}$ and $\mathrm{Na}$ were higher in soils than in plants with a Tf ranking order of $\mathrm{Na}>\mathrm{K}>\mathrm{Mg}>\mathrm{I}$ for both Busia and Lugari regions. Correlation analysis done revealed that the presence of iodine in soils and its uptake and accumulation in reed plants largely depends on the presence of $\mathrm{K}, \mathrm{Na}, \mathrm{Mg}$ in soils surrounding the plant and the plant itself. An increase in plant and soil iodine leads to a decrease in plant and soil $\mathrm{K}, \mathrm{Na}, \mathrm{Mg}$. $\mathrm{K}$ interacts positively with $\mathrm{Na}$, and $\mathrm{Mg}$ in plants and soil but negatively with $\mathrm{Pb}$ in plants and soil. As reported earlier there were high $\mathrm{K}$ and $\mathrm{Na}$ contents in Busia than in Lugari plant reeds hence higher $\mathrm{Na}$ and $\mathrm{K}$ translocation to the salt. This was expected since Busia plants contained higher $\mathrm{Na}$ and $\mathrm{K}$ due to a higher translocation of the same from the soil to the plants as compared to Lugari.

\subsubsection{Recommendations}

It is recommended that indigenous reed salt be sourced from Busia'sCyperus papyrus reeds and obtained from reeds during the wet season. Indigenous reed salt from Busia's $C$. papyrusreeds is more ideal salt for use as table or common salt, since its $\mathrm{Na}$ : K ratio is within the recommended 2.5:1 and 4:1 bracket. On the other hand, Lugari's Typha latifolia salt could be used as a Low-Na salt. There is need to routinely check for heavy metal contamination of the reed salts in order to make safe for human consumption since the results of this study on Cyperus papyrus salt has been shown to contain some considerable levels of heavy metals. It is recommended that further investigations be done to establish the possible sources of these heavy metal contaminants so that they can be eliminated or reduced in the food chain. Meanwhile, people living in this area and other areas with similar activities and plant species are encouraged not to consume large quantities of these salts, so as to minimize or avoid excessive accumulation of heavy metals in their bodies. There is need for a regular and stringent quality control mechanism so that its use in humans and animals is safe.It is therefore recommended that urgent attention is needed to devise and implement appropriate means of monitoring heavy metal concentrations in reed plants used for production of indigenous food additives grown in swampy areas and along river banks, to prevent their excessive build-up in the food chain.

\section{References}

[1] Allaramadji, N., (2011). Contribution to knowledge of use of traditional salts. Master Thesis, Faculty of Science, University of N'Djamena.

[2] Allard, S., Von Gunten, U., Sahli, E., Nicolau, R. \& Gallard, H.(2009). Oxidation of iodide and iodine on birnessite $\left(\right.$ delta- $\left.\mathrm{MnO}_{2}\right)$ inthe $\mathrm{pH}$ range 4-8. Water Research, 43,3417-3426.

[3] AOAC, (2000). Methods of Analysis by Association of Official Analytical Chemists. Washington D.C., USA.

[4] Ashworth, D. J. \& Shaw, G. (2006). A comparison of the soil migration and plant uptake of radioactive chlorine and iodine from contaminated groundwater. Journal of Environmental Radioactivity, 89,61-80.

[5] Błażewicz, A. (2012). A Review of Spectrophotometric and Chromatographic Methods and Sample Preparation Procedures for Determination of Iodine in Miscellaneous Matrices, Macro To Nano Spectroscopy, Dr. Jamal Uddin (Ed.), ISBN: 978-953-51- 0664-7.

[6] Bunzl, K., Albers, B. P., Schimmack, W., Belli, M., Ciuffo, L. \&Menegon, S. (2000). Examination of a relationship between $137 \mathrm{Cs}$ concentrations in soils and plants from alpine pastures. J Environ Radioact., 48, 145-58

[7] Cui, Y. J., Zhu, Y. G., Zhai, R., Huang, Y., Qiu, Y. \& Liang, J. (2005). Exposure to metal mixtures and human health impacts in a contaminated area in Nanning, China. Environment International, 31, 784-790.

[8] Dai, J. L., Zhang, M. \& Zhu, Y. G. (2004). Adsorption and desorption of iodine by various Chinese soils - I. Iodate. Environment International, 30, 525-530.

[9] Dai, J. L., Zhang, M., Hu, Q. H., Huang, Y. Z., Wang, R. Q. \& Zhu, Y.G. (2009). Adsorption and desorption of iodine by various Chinesesoils: II. Iodide and iodate. Geoderma, 153, 130-135.

[10] Demirezen, D. \& A. Aksoy, (2006). Heavy metal contamination of urban soils and street dusts in limits for $\mathrm{Cu}, \mathrm{Zn}, \mathrm{Ni}$ and exceeded for $\mathrm{Cd}$ and $\mathrm{Pb}$. J. Food Qual., 29, 252-265

[11] Fleming, G. A. (1980). Essential micronutrients II: Iodine and selenium. in Applied Soil Trace Elements, B.E. Davies, ed., 199-234, John Wiley \& Sons, Chichester.

[12] Gallard, H., Allard, S., Nicolau, R., Von Gunten, U. \& Croue, J.P. (2009). Formation of Iodinated Organic Compounds by Oxidationof Iodide-Containing Waters with Manganese Dioxide. Environmental Science \& Technology, 43,7003-7009.

[13] Ghani, A., Ali, Z., Ishtiaq, M., Maqbool, M. \& Parveen, S. (2012). Estimation of macro and micro nutrients in some important medicinal plants of Soon Valley, District Khushab, Pakistan. African Journal of Biotechnology, 11(78), 14386-14391.

[14] Grossman, R.B \& Reinsch, T.G. (2002). SSSA Book Series: 5 Methods of Soil Analysis Ch2, Ed. Dane J. H. and Clarke, T. G. Soil Science Society of America, Inc. Madison, Wisconsin, USA .

[15] Gupta, A.K. \& Sinha, S. (2007) Assessment of single extraction methods for the prediction of bioavailability 


\section{International Journal of Science and Research (IJSR) \\ ISSN (Online): 2319-7064 \\ Index Copernicus Value (2013): 6.14 | Impact Factor (2015): 6.391}

of metals to Brassica juncea L. Czern. (var. Vaibhav) grown on tannery waste contaminated soil. Journal of Hazardoius Materials, 149(1), 144-150.

[16] Johnson, C.C. (2003). The geochemistry of iodine and its application to nvironmental strategies for reducing the risks from iodine deficiency disorders (idd). British Geological Survey, DFID kar project R7411, Report $\mathrm{CR} / 03 / 057 \mathrm{~N}$

[17] Johnson, C. C., Strutt, M. H., Hmeurras, M. \& Mounir, M. (2002). Iodine in the environment of the high atlas mountain area of Morocco. British geological survey, department for international development, DFID KAR Project R7411, Commissioned Report CR/02/196N.

[18]Kabaija, E. (1989). Non-conventional indigenous mineral supplements used for cattle feeding, in the pastoral rangeland of Ethiopia. Journal of Tropical Animal Health and Production, 21, 256-262.

[19] Keter, L. K. \& Mutiso, P. C. (2011). Ethnobotanical studies of medicinal plants used by traditional Health Practitioners in the management of diabetes in Lower Eastern Province, Kenya. Journal ofEthnopharmacology, 139, 74-80.

[20] Khan, S., Cao, Q., Chen, B.\& Zhu, Y.G., (2006). Humic acids increase the phytoavailabilityof $\mathrm{Cd}$ and $\mathrm{Pb}$ to wheat plants cultivated in freshly spiked,contaminated soil. Journal of Soils Sediments, 6,236-242.

[21] King'ang'a, N. (2005). Traditional salt. Retrieved 28/3/2007 from http: tilz.tearfund.org/publications.traditional salt.html

[22]Lee, H. S., Cho, Y. H., Park, S. O., Kye, S. H., Kim, B. H. \& Hahm, T. S. (2006). Dietary exposure of the Korean population to arsenic, cadmium, lead and mercury. Journal of Food Compostion Analytical, 19, $31-37$.

[23] Pourgheysari, H., Moazeni, M. \& Ebrahimi, A. (2012). Heavy metal content in edible salts in Isfahan and estimation of their daily intake via salt consumption. International Journal of Environmental Health and Engineering, 1(1), 8.

[24] Provisional manual for soil survey related to dioxins", Soil and Pesticide Division, Water Quality Reservation Bureau, Japan Environment Agency, Jan. 1998

[25] Rodriguez, P. B, Tome, F. V. \& Lozano, J. C. (2002). About the assumption of linearity in soil- to-plant transfer factors for uranium and thorium isotopes and 226Ra. Science Total Environment,284, 167-75.

[26] Schumacher, B. A., Shines, K. C., Burton, J. V. \& Papp, M. L. (2010). A comparison of soil sample homogenisation Techniques,Environmental monitoring system laboratory, Office of researchand development, U.S. Environmental protection agency.

[27] Skaven-Haug, S. V. (1972). Volumetric relations in soil materials, $4^{\text {th }}$ International Peat Congress, Espoo, Finland. Standard methods by Greenberg.

[28] Smolen Ĕ. S.\&Sady, W., (2011a). Influence of soil application of iodine and sucrose on mineral composition of spinach plants. Acta Science Pol. Hortorum Cultus, 10(3), 3-13.

[29] Smolen, Е̌. S., RoĪek, S., Strzetelski, P.\& LedwoĪywSmole, E. I.(2011b). Preliminary evaluation of the influence of soil fertilization and foliar nutrition with iodine on the effectiveness of iodine bio-fortification and mineral composition of carrot. Journal of the Element, 16 (1), 103-114.

[30] Smolen, Е̌ . S., Sady, W., RoĪek, S., LedwoĪywSmole ĔI. \& Strzetelski P., (2011c). Preliminary evaluation of the influence of iodine and nitrogen fertilization on the effectiveness of iodine biofortification and mineral composition of carrot storage roots. Journal of the Element., 16 (2), 275-285.

[31] Soylak, M., Peker D. S. \&Turkoglu, O. (2008). Heavy metal contents of refined and unrefined table salts from Turkey, Egypt and Greece. Environmental Monitoring and Assessment, 143(1-3), 267-72.

[32] Steinberg, S. M., Buck, B., Morton, J. and Dorman, J. (2008a). Thespeciation of iodine in the saltimpacted Black Butte soil seriesalong the Virgin river, Nevada, USA. Applied Geochemistry, 23,3589-3596.

[33] Steinberg, S. M., Schmett, G. T., Kimble, G., Emerson, D. W.,Turner, M. F. \& Rudin, M. (2008c). Immobilization of fissioniodine by reaction with insoluble natural organic matter. Journal ofRadioanalytical and Nuclear Chemistry, 277:175183.

[34] Tie, Y. L. \& H. S. Kueh, (1979).A review of lowland organic soils of Sarawak. Department of Agriculture, Technical Paper 4, Research Branch, Sarawak, Malaysia.

[35] Tome F.V., Rodriguez, M. P. B. \& Lozano, J. C. (2003). Soil-to-plant transfer factors for natural radionuclides and stable elements in a Mediterranean area. Journal of Environmental Radioactivity, 65, 161-75.

[36] Tsheboeng, G., Bonyongo, M. \& Murray-Hudson, M., (2014). Flood variation and soil nutrient content in floodplain vegetation communities in the Okavango Delta. South African Journal of Science., 110, 3-4.

[37]U.S. Department of agriculture, agricultural research service. (2012). USDA National nutrient database for standard reference

[38] Um, W., Serne, R. J. \& Krupka, K. M. (2004). Linearity and reversibility of iodide adsorption on sediments from Hanford, Washington under water saturated conditions. Water Research, 38, 2009-2016.

[39]USEPA, (US Environmental Protection Agency), (2002). Region 9, Preliminary Remediation

[40] Wang, K. E. \& Jiang, S. J. (2008). Determination of iodine and bromine compounds by ion chromatography/dynamicreaction cell inductively coupled plasma mass spectrometry. Analytical Sciences, 24,509-514.

[41] Wang, X., Sato, T., Xing, B. \&Tao, S., (2005). Health risks of heavy metals to the general public in Tianjin, China via consumption of vegetables and fish. Science of the Total Environment, 350, 28-37.

[42] Whitehead, D. C. (1978). Iodine in Soil Profiles in Relation to Iron and Aluminum-Oxides and OrganicMatter. Journal of Soil Science, 29, 88-94.

[43] Whitehead, D. C. (1979). Iodine in the UkEnvironment with Particular Reference to Agriculture. Journal of Applied Ecology, 16,269-279.

[44] WHO. Guideline, (2012). Potassium intake for adults and children. Geneva, World Health Organization (WHO), pp1-42

[45] Yadata, D. (2014). Determination of the Concentration of $\mathrm{K}^{+}, \mathrm{Na}^{+}$and $\mathrm{Fe}^{+2}$ in Achane and Shay River a Case of 


\section{International Journal of Science and Research (IJSR) ISSN (Online): 2319-7064 \\ Index Copernicus Value (2013): 6.14 | Impact Factor (2015): 6.391}

Tepi Town. Universal Journal of Chemistry, 2(4), 5963.

[46] Yamaguchi, N., Nakano, M., Takamatsu, R. \& Tanida, H. (2010). Inorganic iodine incorporation into soil organic matter: Evidencefrom iodine k-edge X-ray absorption near-edge structure. Journal of Environmental Radioactivity, 101, 451- 457.

[47] Yuita, K. \& Kihou, N. (2005). Behavior of Iodine in a Forest Plot, an Upland Field, and a Paddy Field in the Upland Area of Tsukuba, Japan: Vertical Distribution of Iodine in Soil Horizons and Layers to a Depth of $50 \mathrm{~m}$. Soil Science \& Plant Nutrition, 51, 455- 467.
[48] Yuita, K., Tanaka, T., Abe, C. \&Aso, S. (1991) Dynamics of Iodine, Bromine, and Chlorine in Soil. Effect of Moisture, Temperature, and $\mathrm{pH}$ on the Dissolution of the Triadfrom Soil. Soil Science and Plant Nutrition, 37, 61-73.

[49]Zarei, M., Eskandari, M. H. \& Pakfetrat, S. (2011). Determination of Heavy Metals Content of Refined Table Salts. American-Eurasian Journal of Toxicology and Science,3(2), 59-62.

[50]Zhu, Y. G., Huang, Y. Z., Hu, Y., Liu, Y. X. \& Christie, P. (2004). Interactions between selenium and iodine uptake by spinach (Spinacia oleracea L.) in solution culture. Plant and Soil, 261, 99- 105.

\section{Appendices}

\section{Appendix 1: Tf values for soil-plant for respective samples and sampling sites}

\begin{tabular}{|c|c|c|c|c|c|c|c|c|c|c|}
\hline $\begin{array}{l}\text { salt } \\
\text { type }\end{array}$ & $\begin{array}{c}\text { eleme } \\
\text { nt }\end{array}$ & $\begin{array}{c}\text { conc, } \\
\mathrm{mg} / \mathrm{kg}\end{array}$ & $\begin{array}{c}\mathrm{DI}, \\
\mathrm{mg} / \text { dy/person }\end{array}$ & $\begin{array}{c}\text { PTWIs, } \\
\mathrm{mg} / \mathrm{pers} / \mathrm{wk}\end{array}$ & $\begin{array}{c}\text { EDI, } \\
\mathrm{mg} / \mathrm{kg} / \mathrm{dy}\end{array}$ & $\begin{array}{l}\text { salt } \\
\text { type }\end{array}$ & $\begin{array}{c}\text { conc, } \\
\mathrm{mg} / \mathrm{kg}\end{array}$ & $\begin{array}{c}\text { DI, } \\
\mathrm{mg} / \text { dy/person }\end{array}$ & $\begin{array}{c}\text { PTWIs, } \\
\mathrm{mg} / \mathrm{pers} / \mathrm{wk}\end{array}$ & $\begin{array}{c}\text { EDI, } \\
\mathrm{mg} / \mathrm{kg} / \mathrm{dy}\end{array}$ \\
\hline \multirow[t]{5}{*}{1} & Iod & 1.1 & 0.0055 & 0.0385 & 0.0001 & 4 & 7.4 & 0.037 & 0.259 & 0.0006 \\
\hline & $\mathrm{Fe}^{2+}$ & 1 & 0.005 & 0.035 & 0.0001 & & 0.2 & 0.001 & 0.007 & 0 \\
\hline & $\mathrm{Mg}$ & 52.5 & 0.2625 & 1.8375 & 0.0044 & & 48.1 & 0.2405 & 1.6835 & 0.004 \\
\hline & $\mathrm{Na}$ & 3943.8 & 19.719 & 138.033 & 0.3287 & & 21285.6 & 106.428 & 744.996 & 1.7738 \\
\hline & $\mathrm{K}$ & 4635.8 & 23.179 & 162.253 & 0.3863 & & 3819 & 1.9095 & 13.3665 & 0.0318 \\
\hline \multirow[t]{5}{*}{2} & Iod & 0.9 & 0.0045 & 0.0315 & 0.0001 & 5 & 95.6 & 0.478 & 3.346 & 0.008 \\
\hline & $\mathrm{Fe}^{2+}$ & 1 & 0.005 & 0.035 & 0.0001 & & ND & ND & ND & ND \\
\hline & $\mathrm{Mg}$ & 29.2 & 0.146 & 1.022 & 0.0024 & & 38.9 & 0.1945 & 1.3615 & 0.0032 \\
\hline & $\mathrm{Na}$ & 9969.2 & 49.846 & 348.922 & 0.8308 & & 18913.6 & 94.568 & 661.976 & 1.5761 \\
\hline & $\mathrm{K}$ & 8813.5 & 44.0675 & 308.4725 & 0.7345 & & 4294 & 2.147 & 15.029 & 0.0358 \\
\hline \multirow[t]{5}{*}{3} & Iod & 19.5 & 0.0975 & 0.6825 & 0.0016 & 6 & 69.4 & 0.347 & 2.429 & 0.0058 \\
\hline & $\mathrm{Fe}^{2+}$ & 2.3 & 0.0115 & 0.0805 & 0.0002 & & $\mathrm{ND}$ & ND & $\mathrm{ND}$ & ND \\
\hline & $\mathrm{Mg}$ & 156.5 & 0.7825 & 5.4775 & 0.013 & & 15.4 & 0.077 & 0.539 & 0.0013 \\
\hline & $\mathrm{Na}$ & 20099.6 & 100.498 & 703.486 & 1.675 & & 23855.1 & 119.2755 & 834.9285 & 1.9879 \\
\hline & $\mathrm{K}$ & 10047 & 5.235 & 36.645 & 0.0873 & & 4769 & 2.3845 & 16.6915 & 0.0397 \\
\hline
\end{tabular}

$1=$ Typha latifolia salt; $2=$ Cyperus papyrus salt; $3=\mathrm{HSSA} ; 4=\mathrm{SSSA} ; 5=\mathrm{KNSA} ; 6=\mathrm{TCSA}$

Appendix 3: Regression table for Salt variables in wet and dry seasons

\begin{tabular}{|c|c|c|c|c|c|c|c|c|}
\hline Dry season -salts & & Coefficients & Standard Error & t Stat & P-value & Lower $95 \%$ & Upper 95\% & $\mathrm{R}^{2}$ \\
\hline \multirow[t]{5}{*}{$\mathrm{pH}$} & $\%$ Moisture & 0.039915 & 0.018032 & 2.213537 & \begin{tabular}{|l|}
0.091266 \\
\end{tabular} & -0.01015 & 0.089981 & \\
\hline & iodine & -0.23988 & 0.298963 & -0.80237 & 0.569526 & -4.03856 & 3.5588 & \\
\hline & $\mathrm{Fe}^{2+}$ & -11.533 & 11.30063 & -1.02056 & \begin{tabular}{|l|}
0.493522 \\
\end{tabular} & -155.121 & 132.0551 & \\
\hline & $\mathrm{Mg}$ & $\begin{array}{l}-0.03162 \\
\end{array}$ & 0.006079 & -5.20208 & \begin{tabular}{|l|l|}
0.120903 \\
\end{tabular} & -0.10886 & 0.045616 & \\
\hline & $\mathrm{Na}$ & $2.48 \mathrm{E}-05$ & $4.68 \mathrm{E}-06$ & 5.30966 & 0.11851 & $-3.5 \mathrm{E}-05$ & $8.42 \mathrm{E}-05$ & \\
\hline \multirow[t]{5}{*}{ \% Moisture } & iodine & 0.52635 & 1.730436 & 0.304172 & 0.812019 & -21.4609 & 22.51363 & \\
\hline & $\mathrm{Fe}^{2+}$ & -232.083 & 65.40961 & -3.54814 & \begin{tabular}{|l|}
0.174887 \\
\end{tabular} & -1063.19 & 599.0251 & \\
\hline & $\mathrm{Mg}$ & -0.00547 & 0.41686 & -0.01312 & 0.991646 & -5.30218 & 5.291239 & \\
\hline & $\mathrm{Na}$ & 0.001273 & 0.000321 & 3.969967 & 0.157091 & -0.0028 & 0.005348 & \\
\hline & $\mathrm{pH}$ & 13.79299 & 6.2312 & 2.213537 & \begin{tabular}{|l|}
0.091266 \\
\end{tabular} & -3.50759 & 31.09358 & \\
\hline \multirow[t]{5}{*}{ iodine } & $\mathrm{Fe}^{2+}$ & $\begin{array}{l}-16.5569 \\
\end{array}$ & 33.2658 & -0.49772 & \begin{tabular}{|l|}
0.705997 \\
\end{tabular} & -439.239 & 406.1251 & \\
\hline & $\mathrm{Mg}$ & 0.091696 & 0.021679 & 4.229783 & 0.147795 & -0.18376 & 0.367148 & \\
\hline & $\mathrm{Na}$ & 0.000148 & $4.6 \mathrm{E}-05$ & 3.222086 & \begin{tabular}{|l|l|}
0.191579 \\
\end{tabular} & -0.00044 & 0.000732 & \\
\hline & $\mathrm{pH}$ & -2.89037 & 1.121377 & -2.57751 & \begin{tabular}{|l|}
0.235609 \\
\end{tabular} & -17.1388 & 11.35808 & \\
\hline & $\%$ Moisture & 0.01134 & 0.048739 & 0.232674 & 0.827435 & -0.12398 & 0.146661 & \\
\hline \multirow[t]{6}{*}{$\mathrm{Fe}^{2+}$} & $\mathrm{Mg}$ & $\begin{array}{l}-9.37061 \\
\end{array}$ & 23.20522 & $\begin{array}{l}-0.40381 \\
\end{array}$ & \begin{tabular}{|l|l|}
0.755671 \\
\end{tabular} & -304.221 & 285.4797 & \\
\hline & $\mathrm{Na}$ & -0.0189 & 0.01906 & -0.99168 & 0.425866 & -0.10091 & 0.063108 & \\
\hline & $\mathrm{pH}$ & 144.0005 & 81.31302 & 1.77094 & 0.218585 & -205.861 & 493.8622 & \\
\hline & $\%$ Moisture & 14.36987 & 13.05655 & 1.100587 & \begin{tabular}{|l|l|}
0.385836 \\
\end{tabular} & -41.8079 & 70.54769 & \\
\hline & iodine & -30.2632 & 47.72457 & -0.63412 & 0.57105 & -182.144 & 121.6176 & \\
\hline & $\mathrm{Fe}^{2+}$ & -166.75 & 1504.587 & -0.11083 & 0.918751 & -4955.02 & 4621.518 & \\
\hline \multirow[t]{3}{*}{$\mathrm{Mg}$} & $\mathrm{pH}$ & -7.22944 & 3.198291 & -2.26041 & 0.265161 & -47.8676 & 33.4087 & \\
\hline & $\%$ Moisture & -0.31885 & 0.181799 & -1.75387 & \begin{tabular}{|l|}
0.329893 \\
\end{tabular} & -2.62883 & 1.991127 & \\
\hline & iodine & 4.806491 & 1.219403 & 3.941675 & \begin{tabular}{|l|}
0.158173 \\
\end{tabular} & -10.6875 & 20.30048 & \\
\hline
\end{tabular}


International Journal of Science and Research (IJSR)

ISSN (Online): 2319-7064

Index Copernicus Value (2013): 6.14 | Impact Factor (2015): 6.391

\begin{tabular}{|c|c|c|c|c|c|c|c|c|}
\hline & $\mathrm{Na}$ & -0.00046 & 0.000589 & -0.78835 & 0.474588 & $\begin{array}{l}-0.0021 \\
\end{array}$ & 0.001171 & \\
\hline \multirow[t]{5}{*}{$\mathrm{Na}$} & $\mathrm{pH}$ & 3063.164 & 4178.567 & 0.733066 & 0.59729 & -50030.6 & 56156.89 & \\
\hline & $\%$ Moisture & 613.4117 & 237.5208 & 2.58256 & 0.235189 & -2404.58 & 3631.4 & \\
\hline & iodine & -189.483 & 1593.15 & -0.11894 & 0.924637 & -20432.4 & 20053.41 & \\
\hline & $\mathrm{Fe}^{2+}$ & -20725.7 & 50917.68 & -0.40704 & 0.753906 & -667696 & 626244.8 & \\
\hline & $\mathrm{Mg}$ & -289.551 & 367.2887 & -0.78835 & 0.474588 & -1309.31 & 730.2062 & \\
\hline wet season -salts & & Coefficients & Standard Error & t Stat & P-value & Lower 95\% & Upper 95\% & $\mathrm{R}^{2}$ \\
\hline \multirow[t]{6}{*}{$\mathrm{pH}$} & \% Moisture & 0.034592 & 0.013116 & 2.637403 & 0.23072 & -0.13206 & 0.201246 & \\
\hline & iodine & 0.38267 & 0.098043 & 3.903106 & 0.159671 & -0.86308 & 1.628418 & \\
\hline & $\mathrm{Fe}^{2+}$ & -6.08689 & 3.707452 & -1.6418 & 0.348279 & -53.1945 & 41.02076 & \\
\hline & $\mathrm{Mg}$ & -0.00649 & 0.047732 & -0.13606 & 0.913908 & -0.61299 & 0.600002 & \\
\hline & $\mathrm{K}$ & -0.00067 & 0.001348 & -0.49523 & 0.707267 & -0.0178 & 0.016463 & \\
\hline & $\mathrm{Na}$ & $8.56 \mathrm{E}-05$ & $3.41 \mathrm{E}-05$ & 2.510092 & 0.086931 & $-2.3 \mathrm{E}-05$ & 0.000194 & \\
\hline \multirow[t]{6}{*}{$\%$ moisture } & $\mathrm{pH}$ & 5.662921 & 8.582161 & 0.659848 & 0.556487 & -21.6493 & 32.97519 & \\
\hline & iodine & -13.0992 & 9.048751 & -1.44763 & 0.384846 & -128.075 & 101.876 & \\
\hline & $\mathrm{Fe}^{2+}$ & -58.9785 & 166.1199 & -0.35504 & 0.782815 & -2169.73 & 2051.775 & \\
\hline & $\mathrm{Mg}$ & -0.05225 & 0.513923 & -0.10167 & 0.935496 & -6.58226 & 6.477761 & \\
\hline & $\mathrm{K}$ & 0.006047 & 0.031425 & 0.192432 & 0.878974 & -0.39324 & 0.405338 & \\
\hline & $\mathrm{Na}$ & 0.001843 & 0.002095 & 0.879803 & 0.540651 & -0.02478 & 0.028465 & \\
\hline \multirow[t]{6}{*}{ iodine } & $\mathrm{pH}$ & 2.00103 & 0.618854 & 3.233446 & 0.083799 & -0.66168 & 4.663742 & 0.853572 \\
\hline & $\%$ Moisture & -0.08467 & 0.038905 & -2.17627 & 0.161493 & -0.25206 & 0.082727 & \\
\hline & $\mathrm{Fe}^{2+}$ & 1.292954 & 17.00134 & 0.07605 & 0.951678 & -214.73 & 217.3154 & \\
\hline & $\mathrm{Mg}$ & 0.039637 & 0.174471 & 0.227184 & 0.857784 & -2.17723 & 2.256501 & \\
\hline & $\mathrm{K}$ & -0.00176 & 0.001588 & -1.10778 & 0.383346 & -0.00859 & 0.005072 & \\
\hline & $\mathrm{Na}$ & -0.00016 & 0.000226 & -0.68909 & 0.561973 & -0.00113 & 0.000818 & \\
\hline \multirow[t]{6}{*}{$\mathrm{Fe}^{2+}$} & $\mathrm{pH}$ & -0.11983 & 0.072988 & -1.6418 & 0.348279 & -1.04723 & 0.807568 & \\
\hline & \% Moisture & 0.003944 & 0.003374 & 1.168892 & 0.450526 & -0.03893 & 0.04682 & \\
\hline & \begin{tabular}{|l|} 
iodine \\
\end{tabular} & 0.044219 & 0.033419 & 1.323179 & $\begin{array}{l}0.412004 \\
\end{array}$ & -0.3804 & 0.468842 & \\
\hline & $\mathrm{Mg}$ & 0.002778 & 0.002982 & 0.931368 & 0.522613 & -0.03512 & 0.040671 & \\
\hline & $\mathrm{K}$ & $-3 \mathrm{E}-05$ & $8.42 \mathrm{E}-05$ & -0.3532 & 0.783854 & $\begin{array}{l}-0.0011 \\
\end{array}$ & 0.001041 & \\
\hline & $\mathrm{Na}$ & $-2.1 \mathrm{E}-06$ & $3.04 \mathrm{E}-06$ & -0.70521 & 0.5315 & $-1.2 \mathrm{E}-05$ & $7.52 \mathrm{E}-06$ & \\
\hline \multirow[t]{6}{*}{$\mathrm{Mg}$} & $\mathrm{pH}$ & 56.86231 & 37.65514 & 1.510081 & 0.372369 & -421.592 & 535.3162 & \\
\hline & \% Moisture & -5.10605 & 1.740882 & -2.93302 & 0.209184 & -27.2261 & 17.01396 & \\
\hline & \begin{tabular}{|l|} 
iodine \\
\end{tabular} & -47.2214 & 17.24096 & -2.73891 & 0.222862 & -266.289 & 171.8458 & \\
\hline & $\mathrm{Fe}^{2+}$ & 53.34409 & 390.5695 & 0.13658 & 0.913585 & -4909.31 & 5016 & \\
\hline & $\mathrm{K}$ & 0.056308 & 0.016858 & 3.340021 & 0.079144 & -0.01623 & 0.128844 & \\
\hline & $\mathrm{Na}$ & 0.00225 & 0.002404 & 0.93588 & 0.448132 & -0.00809 & 0.012594 & \\
\hline \multirow[t]{6}{*}{$\mathrm{K}$} & $\mathrm{pH}$ & 835.8691 & 245.8074 & 3.400504 & 0.18208 & $\begin{array}{l}-2287.41 \\
\end{array}$ & 3959.149 & \\
\hline & $\%$ Moisture & -106.003 & 11.36423 & -9.32774 & 0.06799 & -250.399 & 38.39363 & \\
\hline & iodine & -853.994 & 112.5465 & -7.58792 & 0.083418 & -2284.03 & 576.0453 & \\
\hline & $\mathrm{Fe}^{2+}$ & 2577.298 & 3208.713 & 0.803219 & $\begin{array}{l}0.569199 \\
\end{array}$ & -38193.3 & 43347.86 & \\
\hline & $\mathrm{Mg}$ & 74.38419 & 5.664941 & 13.13062 & 0.04839 & 2.404281 & 146.3641 & 0.998876 \\
\hline & $\mathrm{Na}$ & -0.12106 & 0.043511 & -2.7823 & 0.068859 & -0.25953 & 0.017411 & \\
\hline \multirow[t]{6}{*}{$\mathrm{Na}$} & $\mathrm{pH}$ & 5902.382 & 2524.03 & 2.338476 & 0.257255 & -26168.5 & 37973.22 & \\
\hline & \% Moisture & 360.0614 & 116.6916 & 3.085581 & 0.199521 & -1122.65 & 1842.769 & \\
\hline & iodine & $\begin{array}{l}-19.557 \\
\end{array}$ & 1155.664 & $\begin{array}{l}-0.01692 \\
\end{array}$ & 0.989228 & -14703.7 & 14664.55 & \\
\hline & $\mathrm{Fe}^{2+}$ & -100852 & 9624.899 & -10.4783 & 0.060573 & -223148 & 21443.64 & \\
\hline & $\mathrm{Mg}$ & -851.603 & 189.6096 & -4.49135 & 0.139469 & -3260.82 & 1557.615 & \\
\hline & $\mathrm{K}$ & -5.95325 & 2.139685 & -2.7823 & 0.068859 & -12.7627 & 0.856182 & \\
\hline
\end{tabular}

Appendix 4: Regression table for salt-plant-soil elemental concentrations

\begin{tabular}{|c|c|c|c|c|c|c|c|c|c|}
\hline & & & Coefficients & Standard Error & t Stat & P-value & Lower $95 \%$ & Upper $95 \%$ & $\mathrm{R}^{2}$ \\
\hline \multirow[t]{6}{*}{ wet season } & iodine & plant & -0.00321 & 0.018245 & -0.17588 & 0.876583 & -0.08171 & 0.075291 & 0.091664 \\
\hline & & soil & 0.005337 & 0.015259 & 0.349781 & 0.759902 & $\begin{array}{l}-0.06032 \\
\end{array}$ & 0.070993 & 0.091664 \\
\hline & $\mathrm{K}$ & plant & 0.259556 & 0.494584 & $\begin{array}{l}0.524796 \\
\end{array}$ & 0.652095 & -1.86847 & 2.38758 & 0.445251 \\
\hline & & soil & 78.36655 & 62.09895 & 1.261963 & 0.334198 & \begin{tabular}{|l|l|}
-188.824 \\
\end{tabular} & 345.5568 & 0.445251 \\
\hline & $\mathrm{Na}$ & plant & -9.7033 & 4.010241 & -2.41963 & 0.13665 & -26.958 & 7.551371 & 0.805746 \\
\hline & & soil & -5.18269 & 4.924235 & -1.05249 & 0.402972 & -26.37 & 16.00458 & 0.805746 \\
\hline Dry season & iodine & plant & $\begin{array}{l}-0.00177 \\
\end{array}$ & 0.026999 & -0.06545 & 0.95193 & -0.08769 & 0.084156 & 0.416709 \\
\hline
\end{tabular}

\section{Volume 5 Issue 4, April 2016}




\section{International Journal of Science and Research (IJSR) \\ ISSN (Online): 2319-7064}

Index Copernicus Value (2013): 6.14 | Impact Factor (2015): 6.391

\begin{tabular}{|l|l|l|l|l|l|l|l|l|l|}
\hline & & soil & 0.02096 & 0.024578 & 0.852806 & 0.456442 & -0.05726 & 0.099178 & 0.416709 \\
\hline & $\mathrm{K}$ & plant & 0.026044 & 0.935007 & 0.027855 & 0.979527 & -2.94956 & 3.001652 & 0.550337 \\
\hline & & soil & 1.532324 & 0.836049 & 1.832817 & 0.164208 & -1.12836 & 4.193005 & 0.550337 \\
\hline & $\mathrm{Na}$ & plant & 0.338841 & 1.112825 & 0.304488 & 0.780657 & -3.20266 & 3.880346 & 0.033031 \\
\hline & & soil & -1.15541 & 9.249791 & -0.12491 & 0.908493 & -30.5924 & 28.28155 & 0.033031 \\
\hline
\end{tabular}

\begin{tabular}{|c|c|c|c|c|c|c|c|c|c|c|}
\hline & & & Iodine/K & Iodine/Na & $\mathbf{K} / \mathbf{N a}$ & K/Mg & $\mathrm{Na} / \mathbf{K}$ & $\mathrm{Na} / \mathrm{Mg}$ & Mg/Iod & $\mathbf{M g} / \mathbf{K}$ \\
\hline \multirow[t]{6}{*}{ Soils } & Busia & BRPU & -0.6174 & 0.6645 & 0.2322 & 1.3336 & 0.1161 & -0.6572 & -0.9791 & 0.6668 \\
\hline & & BRPB & -0.7859 & 0.3489 & 0.4320 & 1.7528 & 0.2160 & -0.2666 & $\begin{array}{l}-0.9673 \\
\end{array}$ & 0.8764 \\
\hline & Lugari & LRPM & $\begin{array}{l}-0.9294 \\
\end{array}$ & -0.8680 & 1.9771 & 1.9936 & 0.9885 & 0.9763 & -0.9523 & 0.9968 \\
\hline & & LRPL & -0.9085 & -0.8424 & 1.9762 & 1.9284 & 0.9881 & 0.9538 & -0.8222 & 0.9642 \\
\hline & \multicolumn{2}{|l|}{ BUSIA } & -0.9262 & -0.7504 & 1.8302 & 0.7919 & 0.9151 & 0.0177 & -0.4943 & 0.3959 \\
\hline & \multicolumn{2}{|c|}{ LUGARI } & -0.8849 & -0.5248 & 1.6186 & 0.6596 & 0.8093 & -0.2673 & -0.5573 & 0.3298 \\
\hline \multirow[t]{6}{*}{ Plants } & Busia & BRPU & -0.1773 & 0.3740 & 1.5401 & -0.5474 & 0.7739 & -0.8227 & -0.5548 & -0.3266 \\
\hline & & BRPB & -0.3056 & 0.5892 & 0.7966 & -0.0169 & 0.3983 & -0.8892 & -0.6026 & -0.0085 \\
\hline & Lugari & LRPM & 0.7305 & 0.7780 & 1.5835 & 1.6497 & 0.7918 & 0.3266 & 0.5384 & 0.8248 \\
\hline & & LRPL & 0.8256 & 0.9252 & 1.7039 & 1.7873 & 0.8519 & 0.5328 & 0.5917 & 0.8937 \\
\hline & \multirow{2}{*}{\multicolumn{2}{|c|}{ BUSIA }} & 0.9978 & 0.9527 & 1.8611 & 1.8018 & 0.9306 & 0.6794 & 0.8702 & 0.9009 \\
\hline & & & 1.0000 & 1.0000 & 2.0000 & 1.9999 & 1.0000 & 1.0000 & 0.9999 & 1.0000 \\
\hline
\end{tabular}

Appendix 6: Correlation table for element concentration in salt versus its presence in plant and soil

\begin{tabular}{|l|l|l|l|l|l|l|l|l|l|}
\hline & salt-I & plant-I & soil- $\mathrm{I}$ & salt $\mathrm{K}$ & plant $\mathrm{K}$ & soil- $\mathrm{K}$ & salt $-\mathrm{Na}$ & plant $\mathrm{Na}$ & soil-Na \\
\hline salt-I & 1.0000 & & & & & & & & \\
\hline plant-I & 0.5247 & 1.0000 & & & & & & & \\
\hline soil-I & 0.6449 & 0.8380 & 1.0000 & & & & & & \\
\hline salt-K & 0.5052 & -0.0396 & -0.2681 & 1.0000 & & & & & \\
\hline plant-K & -0.2011 & -0.4570 & -0.4566 & 0.2164 & 1.0000 & & & & \\
\hline soil-K & 0.0707 & -0.5555 & -0.6521 & 0.7418 & 0.2778 & 1.0000 & & & \\
\hline salt-Na & 0.0318 & 0.5528 & 0.7079 & -0.7014 & -0.0082 & -0.8742 & 1.0000 & & \\
\hline plant-Na & -0.6355 & -0.2595 & -0.3533 & -0.3472 & 0.3201 & -0.4198 & 0.1673 & 1.0000 & \\
\hline soil-Na & -0.8486 & -0.1727 & -0.3432 & -0.5815 & -0.2633 & -0.3596 & 0.0561 & 0.6554 & 1.0000 \\
\hline
\end{tabular}

Appendix 7: Correlation table for various soil properties in the soils samples

\begin{tabular}{|c|c|c|c|c|c|c|c|c|c|c|c|c|c|c|}
\hline wet season & $\begin{array}{c}\text { depth, } \\
\mathrm{cm}\end{array}$ & $p H$ & $\begin{array}{c}\% \\
\text { moisture }\end{array}$ & $\% N$ & \begin{tabular}{|c|} 
CEC \\
meq/lo0g \\
soil \\
\end{tabular} & $\begin{array}{c}\% \\
\text { sand }\end{array}$ & $\%$ silt & $\begin{array}{l}S B D, \\
\mathrm{~g} / \mathrm{cm} 3\end{array}$ & $\begin{array}{c}\% \\
L O I\end{array}$ & $\begin{array}{c}\% \\
\text { clay }\end{array}$ & $\begin{array}{c}P \\
m g / k g\end{array}$ & $\begin{array}{c}I o d \\
m g / k g\end{array}$ & $\begin{array}{c}K \\
m g / k g\end{array}$ & $\begin{array}{c}\mathrm{Na} \\
\mathrm{mg} / \mathrm{kg}\end{array}$ \\
\hline depth, $\mathrm{cm}$ & 1.000 & & & & & & & & & & & & & \\
\hline $\mathrm{pH}$ & -0.308 & \begin{tabular}{|l|}
1.000 \\
\end{tabular} & & & & & & & & & & & & \\
\hline \%moisture & 0.417 & \begin{tabular}{|l|}
-0.653 \\
\end{tabular} & 1.000 & & & & & & & & & & & \\
\hline$\% \mathrm{~N}$ & 0.344 & \begin{tabular}{|l|}
-0.621 \\
\end{tabular} & 0.717 & 1.000 & & & & & & & & & & \\
\hline $\begin{array}{c}\text { CEC } \\
\text { meq/100gsoil }\end{array}$ & -0.215 & $|-0.325|$ & 0.486 & 0.470 & 1.000 & & & & & & & & & \\
\hline \%sand & -0.444 & \begin{tabular}{|l|l|}
0.862 \\
\end{tabular} & -0.801 & -0.795 & -0.367 & 1.000 & & & & & & & & \\
\hline$\%$ silt & 0.537 & \begin{tabular}{|l|}
-0.795 \\
\end{tabular} & 0.689 & 0.607 & -0.041 & -0.907 & 1.000 & & & & & & & \\
\hline SBD, $\mathrm{g} / \mathrm{cm} 3$ & 0.645 & \begin{tabular}{|l|}
0.406 \\
\end{tabular} & -0.339 & -0.283 & -0.715 & 0.337 & -0.094 & 1.000 & & & & & & \\
\hline$\% \mathrm{LOI}$ & 0.307 & \begin{tabular}{|l|}
-0.847 \\
\end{tabular} & 0.831 & 0.808 & 0.610 & -0.960 & \begin{tabular}{|l|}
0.763 \\
\end{tabular} & -0.511 & \begin{tabular}{|l|}
1.000 \\
\end{tabular} & & & & & \\
\hline \%clay & 0.260 & \begin{tabular}{|l|}
-0.757 \\
\end{tabular} & 0.755 & 0.835 & 0.719 & -0.897 & 0.627 & -0.519 & 0.974 & 1.000 & & & & \\
\hline $\mathrm{P}, \mathrm{mg} / \mathrm{kg}$ & 0.311 & \begin{tabular}{|l|}
-0.029 \\
\end{tabular} & -0.351 & -0.414 & -0.046 & 0.230 & -0.254 & 0.388 & -0.201 & \begin{tabular}{|l|}
-0.159 \\
\end{tabular} & 1.000 & & & \\
\hline $\mathrm{Mg} \mathrm{mg} / \mathrm{kg}$ & -0.131 & \begin{tabular}{|l|}
0.900 \\
\end{tabular} & -0.388 & -0.571 & -0.473 & 0.705 & -0.526 & 0.467 & -0.754 & -0.750 & -0.218 & & & \\
\hline Ca mg/kg & -0.138 & \begin{tabular}{|l|}
0.080 \\
\end{tabular} & 0.397 & -0.259 & -0.018 & 0.069 & \begin{tabular}{|l|}
0.054 \\
\end{tabular} & -0.203 & \begin{tabular}{|l|}
-0.049 \\
\end{tabular} & |-0.191 & -0.350 & & & \\
\hline Iod $\mathrm{mg} / \mathrm{kg}$ & -0.145 & \begin{tabular}{|l|}
0.772 \\
\end{tabular} & -0.135 & -0.252 & -0.286 & 0.570 & -0.460 & 0.310 & -0.582 & \begin{tabular}{|c|}
-0.572 \\
\end{tabular} & -0.465 & 1.000 & & \\
\hline $\mathrm{K} \mathrm{mg} / \mathrm{kg}$ & $\begin{array}{l}-0.049 \\
\end{array}$ & \begin{tabular}{|l|l|}
0.489 \\
\end{tabular} & 0.005 & -0.268 & -0.441 & 0.158 & 0.066 & 0.197 & -0.279 & \begin{tabular}{|l|}
-0.362 \\
\end{tabular} & -0.573 & 0.673 & 1.000 & \\
\hline $\mathrm{Na} \mathrm{mg/kg}$ & -0.306 & \begin{tabular}{|l|}
-0.385 \\
\end{tabular} & 0.335 & 0.360 & 0.928 & -0.234 & \begin{tabular}{|l|}
-0.147 \\
\end{tabular} & -0.715 & 0.486 & 0.585 & 0.123 & -0.394 & \begin{tabular}{|l|l|}
-0.681 \\
\end{tabular} & 1 \\
\hline dry season & $\begin{array}{c}\text { depth, } \\
\mathrm{cm}\end{array}$ & $p H$ & $\begin{array}{c}\% \\
\text { moisture }\end{array}$ & $\% N$ & \begin{tabular}{|c|}
$C E C$ \\
meq/lo0g \\
soil \\
\end{tabular} & $\begin{array}{c}\% \\
\text { sand }\end{array}$ & $\begin{array}{c}\% \\
\text { silt }\end{array}$ & $\begin{array}{l}S B D, \\
\mathrm{~g} / \mathrm{cm} 3\end{array}$ & $\begin{array}{c}\% \\
L O I\end{array}$ & $\begin{array}{c}\% \\
\text { clay }\end{array}$ & $\begin{array}{c}P \\
m g / k g\end{array}$ & $\begin{array}{c}I o d \\
m g / k g\end{array}$ & $\begin{array}{c}\mathrm{Na} \\
\mathrm{mg} / \mathrm{kg}\end{array}$ & \\
\hline depth, cm & 1 & & & & & & & & & & & & & \\
\hline $\mathrm{pH}$ & -0.312 & 1 & & & & & & & & & & & & \\
\hline \%moisture & 0.000 & \begin{tabular}{|l|}
0.254 \\
\end{tabular} & 1.000 & & & & & & & & & & & \\
\hline$\% \mathrm{~N}$ & 0.055 & \begin{tabular}{|l|l|}
0.156 \\
\end{tabular} & 0.767 & 1.000 & & & & & & & & & & \\
\hline $\begin{array}{c}\text { CEC } \\
\text { meq/100gsoil }\end{array}$ & -0.098 & 0.441 & 0.394 & 0.438 & 1.000 & & & & & & & & & \\
\hline \%sand & -0.150 & \begin{tabular}{|l|}
-0.141 \\
\end{tabular} & -0.828 & -0.762 & -0.295 & 1.000 & & & & & & & & \\
\hline
\end{tabular}

Volume 5 Issue 4, April 2016

www.ijsr.net 
International Journal of Science and Research (IJSR)

ISSN (Online): 2319-7064

Index Copernicus Value (2013): 6.14 | Impact Factor (2015): 6.391

\begin{tabular}{|c|c|c|c|c|c|c|c|c|c|c|c|c|c|c|}
\hline$\%$ silt & 0.150 & 0.002 & 0.750 & 0.601 & -0.058 & -0.931 & 1.000 & & & & & & & \\
\hline $\mathrm{SBD}, \mathrm{g} / \mathrm{cm} 3$ & 0.557 & -0.200 & -0.239 & -0.237 & -0.622 & 0.273 & -0.088 & 1.000 & & & & & & \\
\hline$\%$ LOI & 0.097 & 0.227 & 0.843 & 0.786 & 0.526 & -0.967 & 0.815 & -0.420 & 1.000 & & & & & \\
\hline \%clay & 0.118 & 0.283 & 0.767 & 0.815 & 0.667 & -0.897 & 0.674 & -0.444 & 0.971 & 1.000 & & & & \\
\hline $\mathrm{P}, \mathrm{mg} / \mathrm{kg}$ & -0.018 & 0.073 & -0.002 & -0.070 & 0.051 & 0.147 & -0.183 & 0.323 & -0.113 & -0.075 & 1.000 & & & \\
\hline $\mathrm{Mg}, \mathrm{mg} / \mathrm{kg}$ & -0.262 & 0.403 & -0.068 & -0.129 & 0.066 & -0.094 & 0.078 & -0.404 & \begin{tabular}{|l|}
0.090 \\
\end{tabular} & 0.095 & -0.344 & & & \\
\hline $\mathrm{K}, \mathrm{mg} / \mathrm{kg}$ & -0.218 & 0.256 & -0.534 & -0.473 & -0.192 & 0.498 & -0.460 & -0.040 & -0.506 & -0.453 & -0.035 & & & \\
\hline Iod $\mathrm{mg} / \mathrm{kg}$ & 0.271 & 0.360 & 0.561 & 0.670 & 0.433 & -0.587 & 0.413 & 0.147 & 0.617 & 0.695 & 0.035 & 1.000 & & \\
\hline $\mathrm{Na}, \mathrm{mg} / \mathrm{kg}$ & -0.308 & 0.383 & 0.438 & 0.247 & 0.886 & -0.206 & -0.075 & -0.590 & 0.424 & 0.509 & 0.205 & 0.327 & 1 & \\
\hline
\end{tabular}

Appendix 8: Regression table for chemical characteristics of the reed Plants

\begin{tabular}{|c|c|c|c|c|c|c|c|}
\hline \multicolumn{8}{|l|}{ plants-dry season } \\
\hline \multicolumn{2}{|l|}{ Dry season } & Coefficients & Standard Error & t Stat & P-value & Lower 95\% & Upper 95\% \\
\hline \multirow[t]{2}{*}{ iodine } & $\mathrm{Na} \mathrm{mg/kg}$ & 0.00682 & 0.001788 & 3.813843 & 0.163249 & -0.0159 & 0.029542 \\
\hline & $\mathrm{K} \mathrm{mg} / \mathrm{kg}$ & -0.06924 & 0.031522 & -2.19651 & 0.27198 & -0.46977 & 0.331288 \\
\hline \multirow[t]{2}{*}{$\mathrm{Na}$} & $\mathrm{K} \mathrm{mg} / \mathrm{kg}$ & 10.24321 & 3.391211 & 3.020516 & 0.203535 & -32.8462 & 53.33262 \\
\hline & Iod $\mathrm{mg} / \mathrm{kg}$ & 137.1926 & 35.97227 & 3.813843 & 0.163249 & -319.878 & 594.2635 \\
\hline \multirow[t]{2}{*}{$\mathrm{K}$} & Iod $\mathrm{mg} / \mathrm{kg}$ & -11.9632 & 5.446435 & -2.19651 & 0.27198 & -81.1667 & 57.24035 \\
\hline & $\mathrm{Na} \mathrm{mg/kg}$ & 0.087982 & 0.029128 & 3.020516 & 0.203535 & -0.28213 & 0.458091 \\
\hline plants-wet season & & Coefficients & Standard Error & t Stat & P-value & Lower 95\% & Upper $95 \%$ \\
\hline \multirow[t]{3}{*}{ Iodine } & $\mathrm{Mg} \mathrm{mg} / \mathrm{kg}$ & 1.191945 & 7.222694 & 0.165028 & 0.884094 & -29.8848 & 32.26869 \\
\hline & $\mathrm{K} \mathrm{mg} / \mathrm{kg}$ & -0.01474 & 0.022226 & -0.66309 & 0.543532 & -0.07645 & 0.046971 \\
\hline & $\mathrm{Na} \mathrm{mg} / \mathrm{kg}$ & -0.02025 & 0.028184 & -0.71844 & 0.512215 & -0.0985 & 0.058003 \\
\hline \multirow[t]{3}{*}{$\mathrm{Mg}$} & Iod $\mathrm{mg} / \mathrm{kg}$ & -0.06334 & 0.165562 & -0.38259 & 0.767371 & -2.167 & 2.040319 \\
\hline & $\mathrm{K} \mathrm{mg} / \mathrm{kg}$ & 0.001622 & 0.001262 & 1.284973 & 0.268162 & -0.00188 & 0.005126 \\
\hline & $\mathrm{Na} \mathrm{mg/kg}$ & -0.0007 & 0.0016 & -0.4384 & 0.683731 & -0.00515 & 0.003742 \\
\hline
\end{tabular}

